\title{
Quantum (In)Justice: Rethinking the Calculation of Compensation and Damages in ISDS
}

\author{
Toni Marzal \\ School of Law, University of Glasgow, Glasgow, United Kingdom \\ antonio.marzal@glasgow.ac.uk
}

\begin{abstract}
The present article seeks to critically rethink the key issue of how compensation and damages are and should be calculated in the context of investor-State arbitration - the 'quantum' question, as is commonly referred to in arbitral practice. We will make three main claims: first that such calculations are premised on a fundamental consensus that presents the work of arbitrators in this area as essentially uncontroversial factfinding operations and has led to an inflation of awards, second that this consensus is in reality built on a series of myths and unjustifiable assumptions, and third that the realization that this is so should lay the ground for more acceptable calculations.
\end{abstract}

\section{Keywords}

compensation - damages - discounted cash flow - international investment arbitration - legitimate expectations - valuation

Introduction

The present article seeks to critically rethink the key issue of how compensation and damages ${ }^{1}$ are and should be calculated in the context of investor-State

1 Scholars often distinguish between the terms 'compensation' and 'damages', using the first to refer to the amount of money that a State needs to pay to an investor as a condition for the legality of an act of expropriation, and the second to the amount of money owed as a remedy for a treaty breach (both expropriatory and non-expropriatory). See Irmgard Marboe, 'Compensation and Damages in International Law - The Limits of "Fair Market Value"' (2006) 7 JWIT 723. 
arbitration - the 'quantum' question, as is commonly referred to in arbitral practice. We will make three main claims. First, that such calculations are premised on a fundamental consensus that presents the work of arbitrators in this area as essentially uncontroversial fact-finding assessments, and has the effect of justifying a general inflation in the amounts awarded. Second, that this consensus is in reality built on a series of myths and unjustifiable assumptions. Third, that the realisation that this is so should lay the ground for more acceptable principles on quantum, in ways that we will explore.

Until relatively recently, the lack of attention paid to the calculation of compensation and damages in investor-State dispute settlement (ISDS) was still the object of a common complaint. ${ }^{2}$ How is it possible, it was said, that the question of how much money the State will end up paying the investor, that which matters the most to the parties in dispute, does not occupy a central space in the study of international investment law? That plea, however, has seemingly been answered since around the mid-20oos, with the proliferation of a series of books, ${ }^{3}$ edited volumes, ${ }^{4}$ articles $^{5}$ and even a journal ${ }^{6}$ dedicated exclusively to this issue. Arbitral practice has also answered the call to take

2 Serge Lazareff, 'Assessing Damages: Are Arbitrators Good at It? Should They Be Assisted by Experts? Should They Be Entitled to Decide ex aequo et bono? Some War Stories' (2005) 6 JWIT 17 ('Assessing damages is the parent pauvre of arbitration, the neglected aspect').

3 Irmgard Marboe, Calculation of Compensation and Damages in International Investment Law (2nd edn, OUP 2017); Sergey Ripinsky and Kevin Williams, Damages in International Investment Law (BIICL 2008); Mark Kantor, Valuation for Arbitration: Compensation Standards, Valuation Methods and Expert Evidence (Kluwer Law International 2008); Herfried Wöss and others, Damages in International Arbitration Under Complex Long-term Contracts (OUP 2014); Borzu Sabahi, Compensation and Restitution in Investor State Arbitration (OUP 2011).

4 Yves Derains and Richard H Kreindler (eds), Evaluation of Damages in International Arbitration (ICC Pub 2006); Christina Beharry (ed), Contemporary and Emerging Issues on the Law of Damages and Valuation in International Investment Arbitration (Brill Nijhoff 2018); John A Trenor (ed), Guide to Damages in International Arbitration (3rd edn, Global Arbitration Review 2019).

5 To name only some: Thomas Wälde and Borzu Sabahi, 'Compensation, Damages, and Valuation' in Peter Muchlinski, Federico Ortino and Christoph Schreuer (eds), The Oxford Handbook of International Investment Law (OUP 2008) 1049; Marboe (n 1); Steven Ratner, 'Compensation for Expropriations in a World of Investment Treaties: Beyond the Lawful/ Unlawful Distinction' (2017) 111 AJIL 7; Diane Desierto, 'The Outer Limits of Adequate Reparations for Breaches of Non-Expropriation Investment Treaty Provisions: Choice and Proportionality in Chorzów' (2017) 55 Colum J Transnatl L 395; Zeno Crespi Reghizzi, 'General Rules and Principles on State Responsibility and Damages in Investment Arbitration: Some Critical Issues' in Andrea Gattini, Attila Tanzi and Filippo Fontanelli (eds), General Principles of Law and International Investment Arbitration (Brill Nijhoff 2018) 58.

6 The Journal of Damages in International Arbitration was launched in 2014. 
these calculations seriously, with tribunals engaging more and more with the intricate details of valuation, and sometimes addressing quantum issues in a separate award that can extend to several hundreds of pages. ${ }^{7}$

In parallel, there has been a growing disquiet at the sheer amounts that have been awarded, as these seem to be constantly increasing ${ }^{8}$ and reaching, in some notable cases, multi-billion figures. Among such mega-awards, as they are sometimes labelled, we may cite TCC $v$ Pakistan (USD 5.84 billion), ${ }^{9}$ Occidental v Ecuador (USD 2.3 billion), ${ }_{10}^{10}$ Yukos $v$ Russia (USD 50 billion), ${ }_{1}^{11}$ or ConocoPhillips $v$ Venezuela (USD 8.7 billion), ${ }^{12}$ all of which amount to the staggering fraction of around $2 \%$ of the GDP of the respective countries. Exactly what is wrong with these numbers has nevertheless not been clearly articulated. On the side of the apologists, it is often said that they simply reflect the magnitude of the financial interests at stake, ${ }^{13}$ while on the side of the critics, more often than not they are used as flashy evidence against international investment law as a whole, rather than to challenge the specific principles that guide the calculation of compensation/damages.

Over the last couple of years, however, those principles have finally made their way into the ISDS reform agenda. Within the modernisation process of the Energy Charter Treaty, 'Valuation of damages' has been included as one of the approved topics. ${ }^{14}$ UNCITRAL Working Group III, charged with addressing ISDS reform, has incorporated 'damages' as a cross-cutting issue.

7 See eg Tethyan Copper Co Pty Ltd v Islamic Rep of Pakistan, ICSID Case No ARB/12/1, Award (12 July 2019) (620 pages), ConocoPhillips Petrozuata BV, ConocoPhillips Hamaca $B V \&$ ConocoPhillips Gulf of Paria BV v Bolivarian Rep of Venezuela, ICSID Case No $\mathrm{ARB} / 07 / 3 \mathrm{O}$, Award (8 March 2019) (331 pages). According to a 2015 study, the average number of pages dedicated to quantum went from eight (before 2000) to 34 (from 2011 to 2015): PwC, International Arbitration Damages Research: Closing the Gap Between Claimants and Respondents (PwC 2015).

8 Jonathan Bonnitcha and Sarah Brewin, 'Compensation Under Investment Treaties' (IISD 2020) App A (listing the 50 known awards in excess of USD 100 million, none of which were rendered before 2000 and only 11 before 2010).

$9 \quad \operatorname{TCC} v$ Pakistan (n 7$)$.

10 Occidental Petroleum Corp \& Occidental Exploration and Production Co $v$ Rep of Ecuador, ICSID Case No ARB/o6/11, Award (5 October 2012). The sum was reduced to USD 1.062 billion by an ICSID annulment committee: Decision on Annulment of the Award (2 November 2015).

11 Yukos Universal Ltd $v$ The Russian Federation, PCA Case No AA 227, UNCITRAL, Award (18 July 2014).

12 ConocoPhillips v Venezuela $\left(\mathrm{n}_{7}\right)$.

13 Irmgard Marboe, Damages in Investor-State Arbitration: Current Issues and Challenges (Brill 2018) 4.

14 Energy Charter Conference, 'Approved Topics for the Modernisation of the Energy Charter Treaty' (2018). 
Concerns nevertheless remain extremely generic - they are identified as the risk that a 'high amount of damages' may have a regulatory chill effect, ${ }^{15}$ and the fear that calculations may be 'incorrect'. ${ }^{16}$ And yet, how high is too high, what exactly is 'correct'? The answer to these questions remains elusive. On the whole, it would seem that the only real problem with the way compensation/damages are currently quantified is that it is unpredictable and incoherent, ${ }^{17}$ due in great part to the huge discretion wielded by tribunals ${ }^{18}$ and to the existence of an 'underdeveloped body of rules'. ${ }^{19}$ Indeed, the issue around quantum is linked in the UNCITRAL reform agenda to general '[c]oncerns relating to the lack of consistency, coherence, predictability and "correctness" of arbitral decisions. ${ }^{20}$ Proposed solutions also focus on consistency: it has been suggested that the review for errors of fact and law in a reformed annulment procedure should be expanded in relation to the assessment of damages, ${ }^{21}$ that the 'evidence required and the methods used for the calculation of damages' should be clarified, ${ }^{22}$ or that 'valuation criteria shall be based on internationally recognised principles and norms. ${ }^{23}$

It is submitted that, contrary to widespread belief, calculations of compensation/damages are actually remarkably consistent in current arbitral practice. Indeed, the said practice has evolved over the last three decades in a very particular direction, one that draws a sharp break with how compensation was approached in the past, and which today can be said to show a rare consensus.

15 UNCITRAL, 'Report of Working Group III (Investor-State Dispute Settlement Reform) on the Work of Its Thirty-Seventh Session' (1-5 April 2019) UN Doc A/CN.9/970, para 36.

16 ibid para 38.

17 Marboe (n 13) 4 ('What remains a disturbing feature in the area of damages is the lack of consistency in arbitral practice').

18 See eg Charles Jarrosson, 'Lévaluation du préjudice par l'arbitre: Rapport introductif' (2015) Revue de l'arbitrage 347.

19 Pierre-Yves Tschanz and Jorge Viñuales, 'Compensation for Non-Expropriatory Breaches of International Investment Law: The Contribution of the Argentine Awards' (2009) 26 JIA 729, 739 .

20 The Working Group has sought to rely in this respect on the work of the ICCA-ASIL Task Force on Damages, whose mission is to promote 'consistency and rigor' < www.arbitration -icca.org/projects/ICCA-ASIL-Task-Force-on-Damages.html> accessed 19 February 2021.

21 UNCITRAL, 'Report of Working Group III (Investor-State Dispute Settlement Reform) on the Work of Its Resumed Thirty-Eighth Session' (20-24 January 2020) UN Doc A/ CN.9/1004/Add.1, para 28.

22 Columbia Center on Sustainable Investment, International Institute for Environment and Development (IIED) and International Institute for Sustainable Development, 'UNCITRAL Working Group III on ISDS Reform: How Cross-Cutting Issues Reshape Reform Options' (15 July 2019).

23 EU Revised Text Proposal for the Modernisation of the Energy Charter Treaty (27 May 2020). 
Whilst it is true that the specific amount of damages that will be awarded in any particular instance is hard to predict, what principles will be applied to get there are not. It is also the case, as we will explain, that the current consensus has justified the massive inflation of awards that we observe today. The problem with current practice is not, therefore, its supposed inconsistency or excessive discretion, but the questionable assumptions on which it is built, assumptions that lead to unjustifiably large awards. Our aim is not, therefore, to suggest alternative treaty standards that States should incorporate in future investment agreements, as two authors have recently (and interestingly) suggested..$^{24}$ Our contention is more straightforward: tribunals are wrong to interpret the law in relation to calculation of compensation/damages the way they do.

The article is divided into three main parts. The first seeks to identify how the current arbitral practice has achieved a remarkable consistency, in a way that has generally served to justify the inflation of awards. This consistency derives from the idea, which only became widespread at the beginning of the gos, that tribunals have almost no margin of appreciation when it comes to quantifying the amount of money owed to the investor in cases of expropriation or breach of investment treaty standards. Quantum, in other words, has come to be seen as a matter of objective necessity, as dictated by a mix of minimal legal materials and economic realities and expertise. The second part will then propose a critique of the current approach, to expose that it is based on a series of contestable choices, none of which are dictated by objective necessity but derive instead, despite pretences to the contrary, from subjective perceptions of what fairness or policy requires. On this basis, arbitral tribunals have constructed a contingent notion of compensable harm that is specific to international investment law, and which determines what it is that investors can claim compensation/damages for. The third and final part will build on this realisation to suggest a more appropriate approach to the calculation of compensation/damages, by treating quantum issues as rights issues. This will involve an assessment of the expectations of investors that, with regards to compensable harm, can be said to be legitimate. We will discuss and illustrate how this alternative approach would work in practice by focusing on one of the questions that is most decisive: the compensability of the loss of future profits,

24 Emma Aisbett and Jonathan Bonnitcha, 'A Pareto-Improving Compensation Rule for Investment Treaties' (8 November 2018) UNSW Law Research Paper No 18-80; Jonathan Bonnitcha and Emma Aisbett, 'Against Balancing: Revisiting the Use/Regulation Distinction to Reform Liability and Compensation Under Investment Treaties' (20 June 2020) SSRN Working Paper. 
which is currently unjustifiably generous. Such an alternative approach, we insist, is de lege lata - it captures how, in our opinion, the calculation of compensation/damages should be performed today by tribunals, regardless of the possible desirability of treaty reform to correct the excesses that we observe in the case law.

\section{The Evolution of the Law of Calculation of Compensation and Damages in ISDS}

The current state of arbitral practice in relation to the calculation of compensation/damages is based on three fundamental pillars. The first is the principle of full compensation (in cases of lawful expropriation) or reparation (in cases of treaty breach), according to which the investor must recover the entirety of the value lost as a result of the State's expropriation/breach, nothing more (no overcompensation) and nothing less (no undercompensation). The second is the standard of 'fair market value' (i.e. an estimate of the price that the investment would be sold for in an open market, hereinafter FMV), by which the principle of full compensation/reparation is given a more precise meaning (to compensate/repair fully means to award the harmed investor an amount of money equal to the decrease in FMV of its investment). The third is a marked preference, in terms of how to determine FMV, for an incomebased approach, i.e. to estimating FMV as equal to the present value of the investment's anticipated future benefits, and in particular for the discounted cash flow (DCF) valuation method, which involves first projecting future cash flows and then subjecting them to a discount rate to account for the time value of money (a dollar today is worth more than a dollar tomorrow) and risk of the cash flows not actually materialising.

Consensus on these three pillars, as well as on how they should be interpreted and applied, is remarkably solid, as we will illustrate below. However, such a consensus is, in reality, a relatively recent phenomenon, since it was not until the turn to the gos that it finally came together. Until that moment, each of the three pillars was questioned, restricted or even flatly rejected. What brought about this radical transformation? Our main contention here is that this did not reflect, for the most part, any fundamental modification in the rules formally in force. Instead, it is owed to a more profound shift in the legal reasoning of tribunals, which has made the three pillars of full compensation/ reparation, FMV and DCF seem unquestionable - as shown by the reluctance to challenge them of even the counsels for the States. That shift can be broken down into the following three assumptions, whose emergence we will track in 
turn below, bringing forth the idea that tribunals have no choice other than to calculate compensation/damages in the way they currently do, but also resulting to a great extent in the inflation of awards that we observe today. First, that full compensation/reparation and FMV are universal standards, which transcend treaty and State practice, as well as the competing interests and politics of the States involved (2.1). Second, that full compensation/reparation is an objective measure, which means that the quantum assessment is conceived essentially as a fact-finding operation - one that, crucially, excludes considerations of equity, fairness or policy-related (2.2). Third and finally, that the process whereby the investor's loss is transformed into a monetary equivalent (i.e. the valuation process) should not be guided by law but by economic and financial expertise, which has justified inter alia the widespread use of the DCF method (2.3).

\subsection{Exit Politics: The Universality of Full Compensation/Reparation}

For those who observe the very technical discussions that currently surround the assessment of compensation/damages in ISDS, it may be surprising to learn that, until relatively recently, the issue of investor compensation was at the centre of one of the most heated and politicised debates in international law, which arose in relation to the expropriation of foreign assets.

Starting with the Soviet and Mexican nationalisations in the early zoth century, all the way through the post-WWII period of decolonisation and until the decade of the 8os, international investment law was consumed by a passionate discussion about the extent and even existence of the obligation to compensate foreign investors for acts of expropriation. ${ }^{25}$ During this period, communist and Third World States often chose to nationalise or expropriate foreign investments, as a way to assert sovereignty over their local economies and natural resources and free themselves of the yoke of the ex-colonial powers. This created a seemingly insoluble opposition between capital-exporting and capital-importing States. ${ }^{26}$ Whereas the former argued that States could only lawfully expropriate under international law on condition that they provided 'prompt, adequate and effective' compensation to the investor, amounting to the full FMV of the expropriated assets (what is known as the Hull formula), the latter disputed any right to compensation or held that it was only 'partial' in scope (particularly where the expropriation was part of a

25 Andreas Lowenfeld, International Economic Law (2nd edn, OUP 2008) $470 \mathrm{ff}$.

26 Norman Girvan, 'Expropriating the Expropriators: Compensation Criteria from a Third World Viewpoint' in Richard B Lillich (ed), The Valuation of Nationalized Property in International Law, vol III (UP of Virginia 1972-1987) 149. 
broader programme of economic reform). ${ }^{27}$ As the US Supreme Court stated in 1964:

The disagreement as to relevant internationallaw standards [of compensation for expropriation] reflects an even more basic divergence between the national interests of capital importing and capital exporting nations and between the social ideologies of those countries that favour state control of a considerable portion of the means of production and those that adhere to a free enterprise system. ${ }^{28}$

In practice, given the absence of any clear standard of customary international law, ${ }^{29}$ compensation was established on a case by case basis through negotiation and political compromise. Disputes would usually be resolved via lump sum agreements, ${ }^{30}$ which made it very difficult to infer the existence of any truly 'legal' rule as to the required amount of compensation. ${ }^{31}$ On the rare occasions that the dispute was submitted to arbitral or judicial fora, adjudicators naturally disagreed and struggled to find an appropriate legal basis for determining the sum of money owed to investors. Although the 1962 UN Resolution on permanent sovereignty over natural resources was adopted with near unanimity, it enshrined only a vague right to 'appropriate' compensation. ${ }^{32}$ Thus, in the famous 1977 LIAMCO award, sole arbitrator Sobhi Mahmassani spoke of the need to reconcile the interests of capital-importing and capitalexporting countries. ${ }^{33}$ On this basis, and relying on 'general principles of law', he held that the expropriated investor was entitled only to 'convenient and equitable' compensation - a standard considerably below that of full compensation and the full FMV of the expropriated concessions. Another possible

27 World Bank, Legal Framework for the Treatment of Foreign Direct Investment, Volume 1: Survey of Existing Instruments (World Bank 1992) 142.

28 Banco Nacional de Cubav Sabbatino, US Supreme Court, 376 US 398 (1964).

29 Burns H Weston and Frank Dawson, "Prompt, Adequate, and Effective"?: A Universal Standard of Compensation' (1961-1962) 3o Fordham L Rev 727; CF Amerasinghe, 'Issues of Compensation for the Taking of Alien Property in the Light of Recent Cases and Practice' (1992) 41 ICLQ 23.

30 Burns H Weston, Richard B Lillich and David J Bederman, International Claims: Their Settlement by Lump Sum Agreements, 1975-1995 (Brill Nijhoff 1999).

31 Lowenfeld (n 25) 485.

32 UNGA, 'Permanent Sovereignty over Natural Resources' (14 December 1962) Resolution 1803 (XVII).

33 Libyan American Oil Co (LIAMCO) v Government of the Libyan Arab Rep, Award (12 April 1977) 17 ILM 3 (1978) para 317. 
compromise was the one reached by the Second Circuit US Court of Appeals, who ruled in Banco Nacional de Cubav Chase Manhattan Bank that, even though the investor was entitled to full compensation, the latter should be based on the Cuban State's enrichment rather than the investor's loss. ${ }^{34}$

Since the late 8os and early 9os, however, prevailing opinion and arbitral practice have evolved considerably. The debate around standards of compensation has practically disappeared and is now seen as 'obsolete and irrelevant'. ${ }^{35}$ With some rare exceptions, ${ }^{36}$ so-called Third World perspectives on this specific issue have entirely vanished, as has any talk of politics and competing interests. In today's arbitral practice, a ruling such as LIAMCO, which seeks to strike a compromise between different political stances, is simply unimaginable. Instead, the general understanding is now that full compensation for acts of expropriation is a universal norm, as is the principle of full reparation for treaty breaches. It is also uncontroversial that the appropriate basis of value to quantify compensation/damages is FMV.

What brought about the sudden disappearance of politics from debates around the quantification of compensation/damages? Two main reasons are usually given, both related to the boom in investment treaty-based arbitration that began in the early gos. The first is the content of investment treaties, on whose basis States began to be widely sued by private investors. ${ }^{37} \mathrm{~A}$ large number include a reference to the Hull formula to define the extent of the States' obligation to indemnify expropriated investors, and refer to FMV as the appropriate basis of value. A typical provision is the one found in the USArgentina BIT, which requires the 'payment of prompt, adequate and effective compensation', and specifies that compensation 'shall be equivalent to the [FMV] of the expropriated investment immediately before the expropriatory action was taken or became known, whichever is earlier. ${ }^{38}$ Similar provisions

34 Banco Nacional de Cuba v Chase Manhattan Bank, US Court of Appeals, 2nd Cir, 658 F.2d 875 (4 August 1981).

35 Shotaro Hamamoto, 'Compensation Standards and Permanent Sovereignty over Natural Resources' in Marc Bungenberg and Stephan Hobe (eds), Permanent Sovereignty over Natural Resources (Springer 2015) 141, 142.

36 The main exception is Muthucumaraswamy Sornarajah's treatise, now in its fourth edition, which continues to approach the issue of compensation for expropriation through an opposition of views between capital-importing and capital-exporting countries: The International Law on Foreign Investment (4th edn, CUP 2017) ch 11.

$37 \quad$ Sabahi (n 3) 93.

38 Treaty Between United States of America and the Argentina Republic Concerning the Reciprocal Encouragement and Protection of Investment (signed 14 November 1991, entered into force 20 October 1994) art IV(1). 
are present in multilateral treaties such as NAFTA ${ }^{39}$ and the ECT. ${ }^{40}$ Some even understand that the Hull formula and FMV are now part of customary international law. ${ }^{41}$

The second reason that is usually given is the expansive reading of investment protection standards by arbitral tribunals. This, in addition to the decreasing frequency of direct expropriations, has meant that investor claims are more often for damages for violations of investor-protection standards, such as the prohibition of indirect expropriation or the obligation of fair and equitable treatment (FET). Rather than apply the Hull formula by analogy, the response of tribunals has been to consider that, since investment treaties almost never contain provisions on remedies for breaches, the latter are governed by the principle of full reparation (a.k.a. restitutio in integrum) under customary international law. This principle ultimately derives from the famous 1928 decision in the Chorzów Factory case, where the PCIJ ruled that an expropriation forbidden by the applicable treaty carried the obligation to restore the investor as closely as possible to the situation immediately prior to the breach. ${ }^{42}$ The Chorzów principle of full reparation is applied without much discussion to all treaty breaches, including non-expropriatory ones, and is said to be codified in the 2001 Articles on State Responsibility. ${ }^{43}$

The formal basis for damages for treaty breaches is thus very different than for compensation for expropriation. ${ }^{44}$ The reality, though, is that full reparation can be easily confused with the Hull standard. Theoretically, the former entitles the investor to restitution as the primary remedy, and only if this is impossible to monetary damages. In practice, however, restitution is often not requested by investors and, where it is, tribunals usually discard it as too

39 North American Free Trade Agreement (signed 17 December 1992, entered into force 1 January 1994) (NAFTA) art 1110.

$40 \quad$ Energy Charter Treaty (signed 17 December 1994, entered into force 16 April 1998) art 13.1.

41 Markham Ball, 'Assessing Damages in Claims by Investors Against States' (2001) 32 ICSID Rev-FILJ 408, 414; Abby Cohen Smutny, 'Some Observations on the Principles Relating to Compensation in the Investment Treaty Context' (2007) 22 ICSID Rev-FILJ 1, 8.

42 Case Concerning the Factory at Chorzów (Germany v Poland) [1928] PCIJ Rep Series A No 17, 47 ('reparation must, as far as possible, wipe out all the consequences of the illegal act and reestablish the situation which would, in all probability, have existed if that act had not been committed').

43 International Law Commission, 'Articles on Responsibility of States for Internationally Wrongful Acts' (2001) UN Doc A/56/10 (ARSIWA) art 31(1) ('The responsible State is under an obligation to make full reparation for the injury caused by the internationally wrongful act'). Some authors have been critical of the extension of the Chorzów principle to non-expropriatory breaches, and of ARSIWA to ISDS (see eg Crespi Reghizzi (n 5) $60-61)$, but this is a separate debate which we will not address in the present article. 
intrusive on State sovereignty, ${ }^{45}$ so damages is really the only option. Moreover, when calculating damages, FMV is generally considered to be the only appropriate basis of value to transform the investor's loss into an equivalent sum of money. Indeed, in cases of complete deprivation of its property, the investor will be entitled to its full FMV; where the deprivation is only partial, damages will be equivalent to the reduction in FMV resulting from the State's breach. ${ }^{46}$ There is some disagreement about whether a treaty breach should carry some additional burden for the State. ${ }^{47}$ Nevertheless, the consensus on an essential point seems solid: regardless of whether the investor is entitled to compensation (for lawful expropriation) or damages (for any form of treaty breach), the key consequence for the State will be an obligation the restore the investment's full FMV. ${ }^{48}$

In reality, however, the predominance of the standards of full compensation/reparation and FMV is ultimately not a product of the proliferation of investment treaties nor can it be pinned to the Chorzów dictum, even if these have certainly contributed to their consolidation. Indeed, the Hull formula is not as omnipresent as would seem and many treaties use alternatives to FMV to define value (e.g. 'genuine value', 'just value', 'true value', etc.), or make a generic reference to value without attempting to define it. ${ }^{49}$ Some of those that do refer to FMV provide nevertheless that this standard is limited in scope, as relevant only to cases where a market actually exists. ${ }^{50}$ Why is it therefore that

45 See eg Eiser Infrastructure Limited \& Energía Solar Luxembourg Sàrl v Kingdom of Spain, ICSID Case No ARB/13/36, Award (4 May 2017) para 425.

46 See infra nn 99-102 and corresponding text.

47 There is in particular a debate about the appropriate valuation date and about whether the victim of a breach should be entitled to compensation for consequential damages (see infra nn 186-88 and corresponding text). See also Ratner (n 5).

48 Dai Tamada, 'Assessing Damages in Non-Expropriation Cases Before International Investment Arbitration' (2009) 52 Jap YB Intl L 309, 314 (noting the increasing difficulty of distinguishing between damages and compensation); Mark Friedman and Floriane Lavaud, 'Damages Principles in Investment Arbitration' in Trenor (n 4) (referring to full reparation as the common rationale for compensation and damages).

49 According to data provided in 2017 by UNCTAD, there is significant variation among BITs, with just over half referring to 'market value' or FMV, about a third including only a reference to 'value', and the rest a combination of other terms such as 'genuine', 'real', 'actual', 'effective' or 'true' value: José Alberro, 'What Should the Standard of Compensation Be Fair Market Value or Fair Value?' (2017) 4 JDIA 1, 3.

$5^{\circ}$ See eg Agreement Between Australia and the Islamic Republic of Pakistan on the Promotion and Protection of Investments (signed 7 February 1998, entered into force 14 October 1998) art 7(2) (compensation for expropriation shall be based on 'market value' unless 'that value cannot be readily ascertained', in which case 'the compensation shall be determined in accordance with generally recognized principles of valuation and equitable principles taking into account the capital invested, depreciation, capital 
tribunals now pay so little attention to these variations? Moreover, in relation to the Chorzów decision, several authors have shown just how questionable its relevance is to modern ISDS, by pointing out that the almost hundred-year old decision dealt only with a State to State dispute, was set against the very particular context of a treaty that sought to preserve the post-WWI status quo, and involved an act of expropriation that was forbidden per se under the said treaty - three key circumstances that set it apart from today's investor-State disputes. Why is it then that the applicability of the Chorzów principle to all treaty breaches in ISDS, expropriatory or not, is treated as a given?

In the emergence of full compensation/reparation and FMV as universal standards, over and beyond the richness, variety and challenges present in treaty and State practice, the most decisive intervention is probably that of the World Bank, through the publication in 1992 of its Legal Framework for the Treatment of Foreign Direct Investment, and particularly the Guidelines published as its volume 2. Those Guidelines built on a prior document (volume 1, Survey of Existing Instruments), whose purpose was to capture the then current state of international law with regards to the treatment of foreign investors based on a triple analysis of international treaties, decisions of tribunals and opinions of scholars, and domestic investment codes. The analysis showed, unsurprisingly, that the picture was extremely complex with regards to compensation for expropriation, and that the FMV standard was far from universal. About half of 253 surveyed BITs included a reference to the Hull formula, but alternative formulas were used by the remaining ones (such as 'fair', 'genuine', 'just' or 'equitable' value), and a mere 53 contained an actual reference to FMV or market value. ${ }^{51}$ Within the multilateral instruments, on the other hand, only one (of a total of 25) enshrined the Hull formula, and overall divergences were described as 'so extreme that it is in fact impossible to reconcile the various standards of compensation in one formula., ${ }^{52}$ With regards to national investment codes, only 3 (of a total of 48 ) referred to FMV or market value, while most contained no provision at all on adequate compensation or merely required that it be 'fair' or 'equitable'.53 Finally, scholars were shown to be extremely divided, with many refusing to even accept the existence of a

already repatriated, replacement value, and other relevant factors'); Agreement Between the United Mexican States and the Republic of Cuba on the Reciprocal Promotion and Protection of Investments (signed 3 o May 2001, entered into force 29 March 2002) art 7(2) (compensation shall be equal to 'market value', unless that value is absent in which case it be equal to 'real value').

$51 \quad$ WB Survey (n 27) 48.

$5^{2}$ ibid 88 .

53 ibid 124 . 
standard of 'full compensation', while tribunals were said to be more supportive of the latter ${ }^{54}$ but likely to rely on FMV only where an actual market could be said to exist. ${ }^{55}$

In spite of the results of the survey, the Guidelines state that expropriation must come with 'prompt, adequate and effective' compensation (i.e. the Hull formula), and that "[c]ompensation will be deemed "adequate" if it is based on the [FMV] of the taken asset. ${ }^{56}$ The exact quality of this statement is somewhat ambiguous. The introductory report clearly indicates that the Guidelines are not meant to codify applicable rules but to promote the policies advocated by the World Bank, particularly the promotion of foreign direct investment, 'so that such investments may increase in volume and spread out to as many countries as possible, and so that their flows may be governed only by economic considerations and not be hampered by avoidable non-commercial factors'. ${ }^{57}$ The Guidelines' preference for FMV should therefore be seen as reflecting a deliberate policy decision, rather than international legal practice (which stood in stark contrast to the former, as shown in the survey in volume 1). Nevertheless, the Guidelines on compensation for expropriation are also presented as based on 'consensus' and 'best practices'.58 Building on this ambiguity, this document has henceforth been referred to as capturing the current state of international law - in effect, as a codification that wiped clean prior understandings and conflicts, on the basis of a supposed consensus on compensation for expropriation that extended also to the formally different issue of damages. ${ }^{59}$ Most noticeably, the Commentary on the 2001 Articles on State Responsibility, when dealing with the calculation of damages, cites the Guidelines (as well as two awards of the Iran-US Claims Tribunal) as support for the proposition that FMV is generally the applicable standard. ${ }^{60}$ More recent awards and scholarship, if they think it necessary to offer some

\footnotetext{
54 ibid 142.

55 ibid 145 .

56 World Bank, Legal Framework for the Treatment of Foreign Direct Investment, vol 2: Guidelines (World Bank 1992) 41.

57 ibid 13.

58 ibid 24.

59 AIG Capital Partners, Inc \& CJSC Tema Real Estate Cov Rep of Kazakhstan, ICSID Case No ARB/o1/6, Award (7 October 2003) 89 (describing the Guidelines as the 'missing link' that put an end to the disagreements of the past); Marboe (n 1$) 730$ (describing the Guideline on compensation having to be equal to FMV as 'formulated on the basis of a broad and diligent study on the topic').

6o $\quad$ ARSIWA (n 43) art 36, comm para 22.
} 
justification for holding the State to full compensation/reparation and FMV, will usually invoke the Guidelines and the Commentary as authoritative support. ${ }^{61}$

Thus, even though the Guidelines did not reflect international legal practice but were based instead on a particular policy vision, they are now seen, through a certain slippage effect, as an accurate representation of the status quo. In the same vein, tribunals have tended to avoid paying much attention to the letter of the treaties. Long gone are the days where everything depended on the specific word used to define the extent of compensation, in particular whether the term used was 'appropriate' or 'adequate'62 More recent arbitral practice seems to understand FMV as some kind of a transcendent standard of international law, which investment treaties regardless of their specific wording all seek to capture. Tribunals will justify this on the basis of a now current 'agreement' as to the universality of the Hull formula and the FMV standard agreement by who, it is not clear. According to the Award in AIG v Kazakhstan, for instance: "the battle of the rhetoric on compensation standards" is not won or lost in the choice of words or phrases used: but in the comprehension of their true meaning. Despite the diversity of vague and indefinite terms, there is a growing agreement on a standard of compensation that more closely approximates to a [FMV] (or its equivalent) of the property taken.' ${ }^{63}$ In Vivendi $v$ Argentina, the term used in the applicable BIT to define compensation for expropriation was 'actual value' (rather than FMV), but the Tribunal laconically stated, without any attempt at justifying this interpretation, that the two expressions were 'equivalent', adding that in any case FMV had 'generally been accepted as appropriate compensation for expropriation' ${ }^{64}$ Likewise, the Rumeli $v$ Kazakhstan tribunal laconically equated 'real value' with FMV. ${ }^{65}$ In $C M E v$ Czech Republic, where the applicable BIT mandated that compensation be 'just' and representative of the 'genuine value of the investment affected', the Tribunal claimed that this was essentially the same as the Hull formula or an explicit reference to FMV. No actual reasons were given for this, other than the assumption that investment treaties 'are truly universal in their reach and

61 See eg Rumeli Telekom AS \& Telsim Mobil Telekomunikasyon Hizmetleri AS v Rep of Kazakhstan, ICSID Case No ARB/05/16, Award (29 July 2008) para 8o1.

62 See eg Richard B Lillich, The Valuation of Nationalized Property in International Law: Toward a Consensus or More 'Rich Chaos'? in Lillich (n 26) 183.

63 AIG v Kazakhstan (n 59) 85.

64 Compañia de Aguas del Aconquija SA and Vivendi Universal SA v Argentine Rep, ICSID Case No ARB/97/3, Award (20 August 2007) para 8.2.10.

65 Rumeliv Kazakhstan (n 61) para 786. 
essential provisions', and that the differing expressions used in them to define the extent of compensation are nothing more than 'variations on an agreed, essential theme, namely, that when a State takes foreign property, full compensation must be paid'.66

Ultimately, the emergence of full compensation reflects the idea, fully embraced by most of the investment arbitration community, that it is as much in the interest of developing or capital-importing countries as of the wealthier ones. ${ }^{67}$ This idea is now so entrenched, that it is assumed to necessarily reflect the status quo of international investment law. The reality of State practice points however to a much more complex picture, ${ }^{68}$ with some authors arguing that the applicable standard of compensation should depend on the circumstances. ${ }^{69}$ Recent examples of treaties or model treaties in relation to compensation for expropriation, particularly outside the Western world, confirm that the divergences that the World Bank's Guidelines sought to extinguish are very much alive. India's 2015 model BIT provides that compensation shall be less than the investment's FMV if one or more 'mitigating factors' are present, including 'current and past use of the Investment, including the history of its acquisition and purpose', 'any harm or damage that the Investor or its Investment has caused to the environment or local community that have not been remedied by the Investor or the Investment', or generally 'any other relevant considerations regarding the need to balance the public interest and the interests of the Investment.70 The SADC 2012 model BIT also leaves open the possibility that compensation may be less than FMV, for reasons related to the public interest or to reflect the history of the investment. ${ }^{71}$ Furthermore, the position of domestic or supranational legal systems remains extremely varied, including in Western States ${ }^{72}$ - notable examples are recent

66 CME Czech Rep BV v Czech Rep, UNCITRAL, Partial Award (13 September 2001) para 497 .

67 See eg Haliburton Fales, 'A Comparison of Compensation for Nationalization of Alien Property with Standards of Compensation Under United States Domestic Law' in Lillich (n 26) $173,176$.

68 For a detailed critique of the claim that the Hull formula is a rule of customary law, see Sornarajah $\left(\mathrm{n}_{36} 6\right) \mathrm{ch} 11$.

69 See eg Hamamoto ( $\mathrm{n}_{35}$ ) (disputing the relevance of the Hull formula to large-scale expropriations of a general and impersonal character).

$70 \quad$ India 2015 Model BIT art 5.7.

71 South African Development Community 2012 Model BIT art 6.2.

72 Borzu Sabahi and Nicholas J Birch, 'Comparative Compensation for Expropriation' in Stephan W Schill (ed), International Investment Law and Comparative Public Law (OUP 2010) 755 . 
bank nationalisations ${ }^{73}$ or the case law of the ECtHR, ${ }^{74}$ all of which fall short of full FMV.

Advocates of the latter nevertheless seem to find ways to wipe away any divergence in the name of a transcendent standard of full compensation/ reparation and FMV, often in ways that are transparently ideological. A noted scholar, for instance, after surveying the variety of legal regimes on State liability for harm to economic interests and concluding that these fall short of the prevalent standards in international investment law, warns nevertheless against interpreting the latter's approach to damages in a way that more closely aligns with the practice of domestic legal systems: '[g]enerally, the privileged position of the state is increasingly regarded as ill-founded and lacking in legitimacy. Consequently, caution should be taken not to introduce new criteria allegedly based on "general principles of law" into international investment law, which could then be confronted with the same criticism'. ${ }^{75}$ Such vague references to a general consensus show that, in reality, the principle of full compensation/reparation is ultimately upheld as a norm of natural law, binding on States because of its intrinsic rationality rather than its actual consent - with some authors speaking of a 'fundamental right' of investors 'to see [their] losses redressed, ${ }^{76}$ and of full compensation/reparation as 'ideologyfree' and constitutive of the very function of the law of damages. ${ }^{77}$ This marks a return to the origins of the Hull formula - when writing to the Mexican government in response to the taking of US property, Secretary of State Cordell Hull wrote that 'full, prompt and adequate' compensation is guaranteed 'under every rule of law and equity', and that ' $[t]$ he universal acceptance of this rule of the law of nations, which, in truth, is merely a statement of common justice and fair-dealing, does not ... admit of any divergence of opinion: ${ }^{78}$ Current practice, it seems, is just as intolerant of dissent.

73 N Jansen Calamita, 'The British Bank Nationalizations: An International Law Perspective' (2009) 58 ICLQ 119 (arguing that the nationalisations depart from the Hull formula by not valuing the banks as going concerns).

74 Ursula Kriebaum, 'Regulatory Takings: Balancing the Interests of the Investor and the State' (2007) 8 JWIT 717 (showing that the ECtHR takes a more nuanced approach to compensation, as subject to the principle of proportionality).

75 Irmgard Marboe, 'State Responsibility and Comparative State Liability for Administrative and Legislative Harm to Economic Interests' in Schill (n 72) 377, 411.

76 Campbell McLachlan, Laurence Shore and Matthew Weiniger, International Investment Arbitration: Substantive Principles (2nd edn, OUP 2017) 425.

77 Wöss and others ( $\left.\mathrm{n}_{3}\right)$ paras 2.28 and 2.34 .

78 For this and the remaining exchanges between the United States and Mexican governments, see Lowenfeld (n 25) $475 \mathrm{ff}$. 


\subsection{Exit Equity: The Objectivity of Full Compensation/Reparation}

The universality of full compensation/reparation does not, of course, put an end to every possible discussion. It can only go so far in providing a solution to any dispute. As many have asked, how does one determine what full compensation/reparation requires? ${ }^{79}$ How much money will make the investor 'whole again'? Our submission is that, in interpreting the principle of full compensation/reparation and the FMV standard, investment practice is built on a fundamental consensus, to the effect that both are objective measures. This consensus is less explicitly articulated than the one that exists around the validity of the principle of full compensation/reparation, but is just as strong. It is also equally decisive in shaping tribunals' reasoning, by preventing equitable considerations from making their way into the calculation (in ways that would normally reduce the amounts awarded).

To illustrate what we mean, it is useful to contrast today's practice to the approach that prevailed until relatively recently. Not so long ago, an international tribunal's determination of the right amount owed to the investor was generally understood to necessarily involve some reliance on equitable judgment. The common view was that, even if there was agreement on the applicable standard of compensation (such as full compensation) or even basis of value (such as FMV), there was no truly objective way of establishing how much ought to be paid as damages or compensation. At most, even if the tribunal were deciding on the basis of rules of law rather than ex aequo et bono, one could only 'approximate' an amount that seemed fair in the circumstances. ${ }^{80}$

Equitable considerations could make their way into the tribunal's assessment of damages in two main ways. The first is by considering that, when evaluating the victim's loss and estimating its monetary equivalent, the adjudicator would have to rely on its own subjective perception of what was just or equitable. As put for instance in the Aminoil case, 'it is well known that any estimate in money terms of amounts intended to express the value of an asset, of an undertaking, of a contract, or of services rendered, must take equitable principles into account'. 81 In other words, the quantification of compensation/ damages was not seen as a purely fact-finding operation, but as inseparable

79 Sergey Ripinsky, 'Assessing Damages in Investment Disputes: Practice in Search of Perfect' (2009) 10 JWIT 1, 4; Ratner (n 5) 22.

8o See eg American International Group Inc $v$ Islamic Rep of Iran, Award No 93-2-3 (7 December 1983) 4 IUSCTR 96, para 71.

81 American Independent Oil Co v Kuwait, Award (24 March 1982) 21 LM 976, para 78. 
from some measure of equitable judgment. ${ }^{82}$ This may translate, as in the Aminoil award, in the reference to a fair or reasonable rate of return to calculate compensation for lost future profits, ${ }^{83}$ or in the determination of a discount rate that seemed just. ${ }^{84}$ The second way that equity could feature is as an external correction to the valuation process. Having reached a final figure, the arbitrators could take a step back and choose to adjust it if they found it excessive from an equitable perspective. ${ }^{85}$ In the Starrett Housing case, for instance, the Iran-US Claims Tribunal appointed an expert to value the expropriated investment but, once the expert reached a figure, the Tribunal decided to reduce it dramatically to less than $10 \%$ because it considered it inequitable to award more. ${ }^{86}$ This may the case, for instance, where the enforcement of the award might have a ruinous effect on the State's finances. ${ }^{87}$ Here, fact-finding and equitable judgment remain conceptually distinct and take place at different moments of the reasoning, but the overall operation of reaching an amount of compensation/damages necessarily involves both. Other relevant factors could relate to whether the State has acted in bad faith, the public interest rationale behind its conduct, or the history of the investment. ${ }^{88}$

In more recent practice, however, equitable considerations have practically disappeared from the assessment of compensation/damages, including the financial situation of the respondent State. ${ }^{89}$ In the recent Tethyan Copper $v$ Pakistan case, for instance, the decision on quantum is 620 pages long, but contains no references to equity or fairness, despite the enormity of the final award (USD 5.84 billion).${ }^{90}$ From today's standpoint, a reliance on perceptions

$82 \quad$ Norwegian Shipowners' Claims (Norway v United States), Award (13 October 1922) I RIAA 307, 339 ('value must be assessed ex oequo et bono').

83 Aminoil $v$ Kuwait (n 81) para $154 \mathrm{ff}$.

84 Himpurna California Energy Ltdv PT PLN (Persero), Final Award (4 May 1999) [2000] XXV YCA 13 para 371 ('Both the [discount] rate and its application reflect a series of adjustments made by the arbitrators in their equitable assessment of the evidence, and, in the circumstances of this case, resolving all doubts in favour of PLN, the debtor').

85 Wälde and Sabahi ( $\mathrm{n}_{5}$ ) 1104-05.

86 Starrett Housing Corp, Starrett Systems Inc, \& Starrett Housing International Inc v Islamic Rep of Iran, Final Award (14 August 1987) 16 IUSCTR 112.

87 Himpurna Award (n 84).

88 Crespi Reghizzi (n 5) 62-63.

89 Marboe ( $\left.\mathrm{n}_{3}\right)$ para 3.373; Martins Paparinskis, 'A Case Against Crippling Compensation in International Law of State Responsibility' (2020) 83 MLR 1246.

9o TCC v Pakistan ( $\mathrm{n}$ 7). This is particularly striking if we bear in mind that the applicable treaty provided that, where the FMV of the expropriated investment could not be 'readily ascertained', the tribunal would rely on 'equitable principles': see Australia-Pakistan BIT (n 5 o) art $7(2)$. 
of fairness, as found in the above cases, is increasingly seen as unsophisticated, or even as naked arbitrariness. ${ }^{91}$ Our submission is that the near disappearance of equity in the contemporary practice of investment tribunals reflects a general shift in the perception of the very nature of the operation of calculating quantum. Quite simply, tribunals now tend to consider that this operation is reducible to a fact-finding operation, free from any discretionary appreciation of what justice may require in the circumstances. This idea can be broken down into two related assumptions: the first relates to the very loss that must be compensated, and the second to how that loss is valued (i.e. transformed into a monetary equivalent).

Turning to the first, the key assumption that now informs the practice of tribunals is that the loss which the principle of full compensation/reparation seeks to undo is a brute fact, one which a tribunal cannot but take cognisance of. ${ }^{92}$ Even if this belief is extremely widespread, it is usually intuitively held rather than expressly articulated. Because the principle of restitutio in integrum is said to require that the victim be restored to the situation it found itself immediately prior to the breach - or the status quo ante, as it is sometimes referred to ${ }^{93}$ - it can be naturally understood that all the tribunal needs to do is determine what the prior situation was. In other words, it is the fact of the pre-breach financial situation that determines the standard that the arbitral tribunal must enforce. The so-called differential method, another version of the same principle, ${ }^{94}$ may convey the same idea, since it consists in identifying the difference between the situation before and after the State's wrongful action: the tribunal's task is to impose damages equal to what is necessary to bring back that status quo ante.

$91 \quad$ See eg Juan Felipe Merizalde Urdaneta, 'Proportionality, Contributory Negligence and Other Equity Considerations in Investment Arbitration' in Ian A Laird and others (eds), Investment Treaty Arbitration and International Law, vol 8 (JurisNet 2015) 301 (criticising how the use of equity 'compromises the predictability of legal standards and the mathematical precision of damages calculations').

92 Abby Cohen Smutny, 'Compensation Due in the Event of an Unlawful Expropriation: The "Simple Scheme" Presented by Chorzów Factory and Its Relevance to Investment Treaty Disputes' in David D Caron and others (eds), Practising Virtue: Inside International Arbitration (OUP 2015) 626, 641 ('the amount of compensation due is a question of fact for the tribunal to assess'); Geoffrey Bereford Hartwell, 'Assessing Damages: Are Arbitrators Good at It? Should They Be Assisted by Experts? Should They Be Entitled to Decide ex aequo et bono? Some War Stories' (2005) 6 JWIT 7 ('the assessment of damages is a matter of fact and not a matter of law or legal theory').

$93 \quad$ Norwegian Shipowners (n 82) 338.

94 Marboe (n 1$) 733$. 
On this basis, commentators have been very critical of any call to reintroduce any idea of fairness introducing in valuation, as in the Aminoil award. That decision's reliance on the notion of reasonable profits is explained by Jan Paulsson as based on the particular circumstances of the case, where allegedly the standard of the reasonable rate of return had been agreed to by the parties. In normal circumstances, Paulsson pursues, there is no reason not to base damages on the purely factual notion of the demonstrable profit stream from the particular venture that has been interrupted.95 Basing the appropriate measure of compensation/damages on some idea of a fair or normal rate of return, Kantor also argues, would be contrary to the principle of full compensation/ reparation, since it would mean that investors would either be undercompensated (if current expectations of future profits were higher) or overcompensated (if the investment was expected to underperform) ${ }^{96}$ - thus again implying that the extent of an investor's loss is an objective assessment, that equity cannot but muddle. The Walter Bau tribunal put forward a similar argument to reject a valuation based on a 'reasonable rate of return' - this 'overshoots or undershoots true expected return, depending on the circumstances at hand, ${ }^{97}$

This approach to loss leaves no room for the tribunal's discretion in calculating compensation/damages - whether it consists in its intuitive perception of what justice requires or in a more complex balancing of countervailing considerations. ' $[\mathrm{M}]$ oral considerations', as referred to by Derains, are entirely external to the principle of full compensation/reparation: 'as soon as the existence of damages is proved beyond any reasonable doubt, the assessment of their extent is not treated by the arbitrators so much as a legal problem, but as the mere exercise of their inherent power to assess any factual situation. ${ }^{98}$ This assumption relates to damages for non-expropriatory breaches as much as for expropriatory ones: even though there was initially some debate ${ }^{99}$ between those that considered that the calculation of damages for violations of FET should be reflective of notions of justice and involve a greater dose of arbitral discretion, ${ }^{100}$ and those that advocated instead for a focus only

95 Jan Paulsson, 'The Expectation Model' in Derains and Kreindler (n 4) 57, 61.

96 Mark Kantor, 'New Age Compensation for Expropriation' (2009) 2 JWELB 155.

97 Walter Bau AG v Kingdom of Thailand, UNCITRAL, Award (1 July 2009) para 14.10.

98 Yves Derains, 'Conclusions' in Derains and Kreindler (n 4) 225, 226-27.

99 Tamada (n 48) $321 \mathrm{ff}$.

100 Ioana Tudor, 'Balancing the Breach of the FET Standard' (2007) 4 TDM (arguing that the calculation of damages for FET violations should include a 'balancing operation'). 
on 'factual elements',101 the latter position has become dominant. It has therefore come to be accepted that the extent of the investor's loss in those cases is just as objective, as measured by a reduction in FMV. ${ }^{102}$

This assumption about the factual nature of the investor's loss is coupled with a second one, which is that the loss can be objectively valued. As a noted commentator wrote already in 199o, 'value' is 'an objective concept with an economic content'.103 Equity should play no role in ascertaining or correcting that value, i.e. in the process of valuation. It could if a reference to equity was included in the applicable standard of compensation (e.g. by providing that investors are entitled only to 'just' compensation), but this is not the case in the majority of investment treaties. The treaty obligation that compensation be the 'full equivalent' of property taken is therefore an 'absolute' rule. ${ }^{104}$

It is certainly the case that tribunals and commentators regularly point out that valuation is a highly complex operation, one that cannot be approached as an 'exact science' or free from all discretion. ${ }^{105}$ The 'discretion' that tribunals refer to, however, is not the one that is inherent to interpretive or equitable

101 Tschanz and Viñuales (n 19) 729-30 (arguing that calculation of damages should focus exclusively on 'two factual elements: the type of asset or of damage which is at stake and the intensity of the interference with the economic position of the investor'). This approach builds on the position taken by a number of awards involving the Argentinian 2001 crisis, where damages for non-expropriatory breaches were analogized to expropriatory ones to justify the applicability of the FMV standard: CMS Gas Transmission Co v Argentine Rep, ICSID Case No ARB/o1/o8, Award (12 May 2005); Azurix Corpv Argentine Rep, ICSID Case No ARB/o1/12, Award (14 July 2006); Enron and Ponderosa Assets v Argentine Rep, ICSID Case No ARB/o1/3, Award (22 May 2007); Sempra Energy v Argentine Rep, ICSID Case No ARB/o2/16, Award (28 September 2007). For a convincing critique: Kathryn Khamsi, 'Compensation for Non-Expropriatory Investment Treaty Breaches in the Argentine Gas Sector Cases: Issues and Implications' in Michael Waibel and others (eds), The Backlash Against Investment Arbitration: Perceptions and Reality (Kluwer Law International 2010) 165 .

102 See eg ESPF Beteiligungs GmbH, ESPF Nr 2 Austria Beteiligungs GmbH and InfraClass Energie GmbH \& Co KG v Italian Rep, ICSID Case No ARB $/ 16 / 5$, Award (14 September 202O) paras $856-58,884$ (refusing any role for equitable considerations, including the public interest rationale of the measures in violation of FET, in applying the standard of full compensation); Eiser $v$ Spain (n 45) para 441 (adopting the FMV standard without any real discussion, despite speaking earlier of the need to justify more fully the extension to non-expropriatory breaches of principles of calculation of damages developed in relation to expropriation).

103 Elihu Lauterpacht, 'Issues of Compensation and Nationality in the Taking of Energy Investments' (1990) 8 JENRL 241, 249.

104 ibid.

105 See eg Vivendiv Argentina (n 64) para 8.3.16. 
assessments. ${ }^{106}$ It relates instead to the sovereign power of tribunals to decide on the relevant facts, particularly where the evidence is inconclusive or particularly complex. ${ }^{107}$ As stated by Ripinsky, the 'impossibility of fixing with mathematic precision the degree of certainty that is required by law leaves room for arbitrators' subjective judgment in each particular case.' ${ }^{108}$ This is necessarily the case with FMV, since it is by nature an 'estimate' of the price that would be paid in the market, ${ }^{109}$ which must be inferred from other evidence, ${ }^{110}$ and involves complicated determinations about market expectations. ${ }^{111}$ Such estimates can, of course, turn out to be wrong, as evidence of fantastical valuations shows. ${ }^{112}$ They are nevertheless mistakes of a factual nature. ${ }^{113}$ Thus, the tribunal's margin of discretionary appreciation, reduced in this way to the power to make a call in situations of factual uncertainty, is consistent with the understanding of valuation as fundamentally a fact-finding operation.

\subsection{Exit Law: The Economic Nature of Value and Valuation}

As a result of the disappearance of any real debate around standards of compensation, and the understanding that full compensation/reparation is an objective measure, attention has shifted almost entirely to the technical complexities of valuation. Quantum decisions now sometimes occupy hundreds of pages, most of which will be dedicated to valuation questions. Despite their complexity and evidence of widely-diverging figures, ${ }^{114}$ current arbitral practice shows once again a remarkable consensus on the validity of

106 See Bernard Hanotiau, 'La détermination et l'évaluation du dommage réparable' in Emmanuel Gaillard (ed), Transnational Rules in International Commercial Arbitration (ICC Pub 1993) 211, 220 (distinguishing between the use of equity where it is impossible to quantify damages with sufficient precision, and as a corrective where the strict application of compensation rules leads to unfair results).

107 Marboe (n 3) para $3.348 \mathrm{ff}$.

108 Ripinsky (n 79) 13. Similarly, see Gold Reserve Inc v Bolivarian Rep of Venezuela, ICSID Case No ARB(AF)/o9/1, Award (22 September 2014) para 686.

109 Marboe (n 3$)$ para $4.38 \mathrm{ff}$.

110 Thomas W Merrill, 'Incomplete Compensation for Takings' (2002) 11 NYU Envtl L J 110, 119-20.

111 William C Lieblich, 'Determining the Economic Value of Expropriated Income-Producing Property in International Arbitrations' (1991) 8 JIA 59, 77 (pointing out that, in determining FMV, the tribunal must only establish what current market operators predict the future will bring).

112 Thomas R Stauffer, 'Valuation of Assets in International Takings' (1996) 17 ELJ 459, $479 \mathrm{ff}$.

113 Anton de Feuardent, 'Notions d'évaluation du préjudice et principales approches financières du dommage' (2015) Revue de l'arbitrage 413, 424.

114 Adam Douglas, 'Procedural Tools to Facilitate the Quantification of Damages in Investor-State Arbitration' in Beharry (n 4) 3, 5 . 
certain key assumptions. Indeed, there is near unanimity to proclaim that the basis of value is necessarily FMV and that the DCF valuation method is the most appropriate whenever the investment is a 'going concern', i.e. where it is projected to continue operations after the State's breach. We have already identified part of the reason why this is so, with regards to the FMV standard it has to do with the belief in the existence of a universally shared standard, building on the ambiguity of the World Bank's 1992 Guidelines. Nevertheless, now we wish to argue that an additional reason why value is today seen as practically synonymous with FMV, and the main reason for the unstoppable rise of DCF as the preferred valuation methodology, is the popularity of the idea that 'value' is not a legal but an economic concept, and that 'valuation' is governed entirely by economic and financial logic rather than by legal principle. It is probably this idea that has contributed the most to the inflation of awards.

With regards first of all to the notion of 'value', it is now widely believed that this is necessarily synonymous with 'FMV', i.e. an estimate of the price the investor would obtain in an open market. ${ }^{115}$ In the past, however, the meaning of value was far from clear. Value, after all, is a relative notion: value to whom? ${ }^{116}$ It used to be open to question in expropriation-related disputes whether the value that the investor was entitled to recover was the price that it would have obtained in the open market or instead that obtained by the State through its expropriatory action. To take two examples from the 8os, whereas the Iran-US Claims Tribunal in AIG $v$ Iran relied on FMV as the basis of value, ${ }^{117}$ the US Court of Appeals for the Second Circuit ruled in Banco Nacional de Cuba $v$ Chase Manhattan Bank that full compensation meant awarding the measure of enrichment obtained by the Cuban State. ${ }^{118}$ Moreover, it was also thought that FMV as a basis of value had a limited application, since it could only be relevant where an active market for the asset in question actually existed. ${ }^{119}$

In current practice, however, any possible discussion has disappeared: it is considered uncontroversial that value is necessarily equal to FMV, that it cannot be anything else. The two will often be used interchangeably, and generic references to value will be understood to mean FMV. ${ }^{120}$ As a result, FMV is held

\footnotetext{
115 Christer Söderlund, 'The Valuation of Lost Profits: Finding It Right' (2005) 6 JWIT 23.

116 Marboe (n 1$) 724$.

$117 A I G v \operatorname{Iran}(\mathrm{n} 80)$ para 57.

118 Banco Nacional de Cubav Chase Manhattan Bank (n 34).

119 WB Survey (n 27) 145; Fales (n 67) 194.

120 CME v Czech Rep (n 66) para 618; W Michael Reisman and Robert D Sloane, 'Indirect Expropriation and Its Valuation in the BIT Generation' (2003) 74 BYIL 115, 138; Manuel A Abdala and Pablo T Spiller, 'Chorzow's Standard Rejuvenated - Assessing Damages in
} 
by tribunals to really be the only valid basis of value. This conclusion applies to cases of lawful expropriation (even where the treaty does not incorporate this standard), but also to damages for treaty breaches (whether they are expropriatory or not). ${ }^{121}$ The consensus around FMV ${ }^{122}$ is so strong that counsel for States will refrain from arguing that the tribunal should refer to any alternative basis of value. ConocoPhillips $v$ Venezuela is an extreme example of how undisputable this is perceived to be: the arbitral tribunal found that the State had acted in 'bad faith' during negotiations by offering an amount in compensation for the expropriation that was not based on the investment's FMV. ${ }^{123}$

The reason why value is now confused with FMV is essentially because value is understood to be an economic concept, ${ }^{124}$ whose meaning is therefore the one given to it in economics ${ }^{125}$ (or at least within mainstream economics). One of the leading treatises on damages in international investment law notes that there is no gap between the economic and legal understanding of value: '[i]n economics, finance and law alike, value of an object or service is understood as the price it would bring in an open and competitive market, as determined by the demand for the object relative to supply' The authors therefore choose to approach value exclusively as FMV, given its 'nearly universal recognition ... as the appropriate standard of value', and noting that, 'of many standards of "value", [FMV] possesses the most lucid content and reflects the general meaning of "value" as a price that an object would bring in a market'. ${ }^{126}$ That value is seen as synonymous with FMV is further illustrated by the fact that the FMV standard is thought to apply regardless of whether an actual market exists for the investment or assets in question. ${ }^{127}$ The tribunal will always be able to determine, via appropriate valuation methods, what the market price would have been had one actually existed. ${ }^{128}$ As explained by Lieblich,

\footnotetext{
Investment Treaty Arbitrations' (2008) 25 JIA 103, 106; Herfried Wöss and Adriana San Román, 'Full Compensation, Full Reparation and the but-for Premise' in Trenor (n 4).

121 Noah Rubins, Vasuda Sinha and Baxter Roberts, 'Approaches to Valuation in Investment Treaty Arbitration' in Beharry (n 4) 171, 174.

122 Sabahi (n 3) 94.

123 ConocoPhillips Petrozuata BV, ConocoPhillips Hamaca BV \& ConocoPhillips Gulf of Paria $B V v$ Bolivarian Rep of Venezuela, ICSID Case No ARB/o7/3o, Decision on Jurisdiction and Merits (3 September 2013).

124 Lauterpacht (n 103) 249.

125 John Gault, 'The Valuation of Lost Profits: Finding It Right' (2005) 6 JWIT 35, 36; Paul D Friedland and Eleanor Wong, 'Measuring Damages for the Deprivation of Income-Producing Assets: ICSID Case Studies' (1991) 6 ICSID Rev-FILJ 400, 404.

126 Ripinsky and Williams (n 3$) 183$.

127 Cohen Smutny (n 41) 9 .

128 Rumeliv Kazakhstan (n 61) para 802.
} 
'[m]arket prices ... are based upon the perceptions of potential buyers and sellers regarding the property's future prospects, and it is possible to analyze, based upon all the available relevant information, what those perceptions would be if there were a market.'. ${ }^{129}$

It is however with regards to valuation, i.e. the operation of determining FMV in any particular case, that the deference to economics is most obvious. ${ }^{130}$ Commentators regularly insist on the fact that determining the value of an investment is not a legal operation, but an economic one. ${ }^{131}$ It is said that treaties that rely on the FMV standard have incorporated an 'economic standard by reference', one that is 'extraneous to law'.132 It is also asserted that ' $[t]$ he exercise of quantifying the quantum is primarily an economic exercise. The tribunal is assessing the value of the taken property and the value in this context is its economic value.'133 Others note that 'the calculation of damages is inherently an economic endeavor', 134 or that the measure of FMV 'is a question of economics and/or accounting and is not (or should not be) a function of any bright-line legal rule'.135 Another version of this claim consists in warning about the incompetence of lawyers in matters related to valuation, which properly belong to economics and valuation experts. ${ }^{136}$

The characterisation of valuation in ISDS as economic or financial rather than legal is not only of theoretical interest. It is here where the turn to economics has had most impact, particularly with regards to valuation methods, contributing the most to the explosion of awards. Indeed, it has justified the now widespread use of DCF, a method that until recently tended to be resisted

\footnotetext{
129 Lieblich (n 111) 63.

130 Jarrosson (n 18) 353; Lucas Montel, La réparation du dommage dans l'arbitrage international (à partir de l'exemple de l'arbitrage international d'investissement) (Univ Paris II doctoral dissertation 2014) $225 \mathrm{ff}$.

131 Cohen Smutny (n 41) 10.

132 Fuad Zarbiyev, 'From the Law of Valuation to Valuation of Law?' in Theresa Carpenter, Marion Jansen and Joost Pauwelyn (eds), The Use of Economics in International Trade and Investment Disputes (CUP 2017) 370, 371.

133 McLachlan, Shore and Weiniger (n 76) 417.

134 J Gregory Sidak, 'Economists as Arbitrators' (2016) 30 Emory Intl L Rev 2105, 2107.

135 Cohen Smutny (n 41) 10.

136 Ball (n 41) 418 ('Valuation is not what lawyers do. ... The lawyer must identify the applicable legal standard. Then he or she must identify the non-legal discipline needed to apply that standard ... The discipline I am referring to is described as a branch of economics. Some might prefer to call the discipline "finance"); Joshua B Simmons, 'Valuation in Investor-State Arbitration: Toward a More Exact Science' (2012) 3o Berkeley J Intl L 196, 198 ('The question of [FMV] poses notable challenges for arbitrators because it relates more closely to finance than law').
} 
by lawyers as excessively speculative, ${ }^{137}$ and which is generally known to lead to much higher amounts. ${ }^{138}$

As pointed out earlier, the DCF method consists in estimating the value of an asset as equal to the cash flows it is projected to generate in the future, subject to a discount rate to account for the time value of money and associated risk. The idea that the value of an asset is ultimately based on its ability to produce future income, on which the DCF method is premised, has been developed for over a century. ${ }^{139}$ Until the 8 os, however, international legal practice seemed to avoid the DCF methodology, preferring instead to focus on book value (i.e. value as recorded in the company's balance sheet, a 'backward-facing' valuation method since, contrary to DCF, it is based on past expenditure rather than future income). ${ }^{140}$ The rare judicial or arbitral pronouncements that addressed quantum issues during this period only exceptionally resorted to DCF. ${ }^{141}$

The 1987 Amoco decision of the Iran-US Claims Tribunal captures best the traditional opposition of legal practice to DCF (as elaborated on in the Tribunal's majority opinion, authored by the Tribunal's president Michel Virally), and the reasons that have led to the disappearance of that resistance (as found in the separate opinion by Judge Brower). The majority's rejection of DCF was premised on the principle that 'no reparation for speculative or uncertain damage can be awarded', which it described as '[o]ne of the best settled rules of the law of international responsibility of States.'.142 The inherently speculative nature of the DCF method, focusing as it does on the future,

137 See eg Wälde and Sabahi (n 5) 1074-75; Ignaz Seidl-Hohenveldern, 'L'Évaluation des dommages dans les arbitrages transnationaux' (1987) 33 Annuaire français de droit international 7, 24 .

138 Bonnitcha and Brewin (n 8) 29-31 (listing the largest investment awards, most of which result from DCF calculations); John D Branson, 'Damages in Investment Arbitration - A Revolutionary Remedy or Reward for Rich Corporations at the Expense of the World's Poor? A Fundamental Examination of Chorzów's Children' (2016) 3 JDIA 33 (arguing that the inflation of awards is largely driven by the increasing use of DCF).

139 See generally Liliana Doganova, 'Discounting the Future: A Political Technology' (2018) 19 economic sociology_the european electronic newsletter 4.

140 Sornarajah (n 36$) 532$.

141 See eg Banco Nacional de Cubav Chase Manhattan Bank (n 34 ) (refusing to treat the investment as a going concern for the purpose of calculating compensation); Amerasinghe (n 29) 6o (noting that the use of DCF by the Iran-US Claims Tribunal remained exceptional). A notable early exception is Lena Goldfields Ltdv USSR, Award (2 September 1930) (applying DCF method to calculate compensation for the termination of a Soviet mining concession, albeit used to determine the measure of enrichment of the State rather than the loss suffered by the concession-holder).

142 Amoco International Finance Corp v Islamic Rep of Iran, Partial Award No 310-56-3 (14 July 1987) 15 IUSCTR 189, para 238. 
means that it is doubtful that it could ever be validly used in international adjudication. ${ }^{143}$ This is not to say, the Tribunal also makes clear, that investors do not commonly employ the DCF in their own investment decisions: 'projections can be useful indications for a prospective investor, who understands how far it can rely on them and accepts the risks associated with them.'144 That does not mean, however, that a tribunal should do the same. In other words, for the purpose of valuation, one should not confuse what is appropriate for a real-life investor with what is appropriate in the legal domain. Each is subject to its own logic and set of rules..$^{145}$

Brower's separate opinion takes a completely different route, leading to the conclusion that DCF is perfectly pertinent to valuation in international adjudication. He does not question the validity of the legal principle against compensation for speculative losses. That principle, however, applies to the very existence of a loss triggering an obligation to compensate, but not to the assessment of its magnitude. In other words, the tribunal must first verify that the investor's loss is proven with some level of certainty (a threshold that the said principle against speculative losses seeks to ensure), but once that threshold is met compensation will be quantified with the help of 'the best available evidence, even though this process be inherently speculative.'146 More importantly, Judge Brower argues that the majority's rejection of the DCF comes from a 'misunderstanding of economics'. ${ }^{147}$ It is thus implied that, with regards to valuation, law ought to follow economics rather than follow an approach of its own. A clear division of labour thus emerges: while legal principles will determine whether the State has incurred liability, the assessment of compensation/damages will primarily be based on economic and financial principles.

The Amoco decision can be seen as a turning point in the use of DCF. Even though Judge Brower's position lost the battle of that case, it won the war of the proper approach to valuation. Indeed, its opinion is regularly cited to

143 ibid: 'As a projection into the future, any cash flow projection has an element of speculation associated with it ... For this very reason it is disputable whether a tribunal can use it at all for the valuation of compensation'.

144 ibid para 239.

145 Seyed K Khalilian, 'The Place of Discounted Cash Flow in International Commercial Arbitrations: Awards by the Iran-United States Claims Tribunal' (1991) 8 JIA 31, 46 ('while investors in the market have a natural tendency to take risks, judicial institutions have a strong inclination towards avoiding those areas which give rise to uncertainty ... there is a big difference between an investment decision in the market and a judicial decision in a court').

146 Concurring Opinion of Judge Brower, Amoco v Iran (n 142) para 26.

147 ibid. 
support the proposition that there is no contradiction between legal principles (such as the non-compensability of speculative losses) and the use of the DCF method. Virally's position, on the other hand, is said by many commentators to be 'economic nonsense', 148 again implying that it ought to be judged from an economic perspective. The tables first turned in the Phillips Petroleum award, rendered only two years after Amoco, with the Tribunal embracing the DCF method. Crucially, the majority opinion justified this, not on the basis of legal principle, but on the perception that DCF is the method that a hypothetical investor would have relied on to determine the purchase price. ${ }^{149}$ Revealingly, Judge Khalilian in his dissenting opinion criticised that the president of the Tribunal, Robert Briner, had opted for the DCF method because of his experience in the business world rather than in international legal practice. ${ }^{150}$ Two further decisions followed, where the Tribunals also turned to DCF to determine compensation. ${ }^{151}$ The World Bank Guidelines then gave their blessing: on the basis of the then current 'consensus' and 'best practices', as mentioned earlier, as well as supposedly of the 'experience in international arbitrations', ${ }^{152}$ they advocated for the DCF method in determining the FMV of 'a going concern with a proven record of profitability'.153 The Guidelines have henceforth also been cited as authority for the legitimacy of DCF in international legal practice. $^{154}$

The key point to emphasise is that the use of DCF has been accepted because it has become a common belief that valuation in the context of ISDS ought to defer to financial practice and expertise. 'Tribunals could not ignore this reality [of the widespread use of DCF by investors] any longer', as an author puts it. ${ }^{155}$ Such deference has also resulted, in more recent case law, in an expansion of the scope of application of that valuation method. Indeed,

148 Lieblich (n 111) 67. See also McLachlan, Shore and Weiniger (n 76) 422; Ratner (n 5) 14, 45.

149 Phillips Petroleum Co Iran v Islamic Rep of Iran, Award No 425-39-2 (29 June 1989) 21 IUSCTR 79, para 112.

$15^{\circ}$ ibid, statement by Judge Khalilian, 'As to Why It Would Have Been Premature to Sign the Award' para 9.

151 Starrett Housing v Iran (n 86); Amco Asia Corp et al v Rep of Indonesia, ICSID Case No ARB/81/1, Award (31 May 1990).

$15^{2}$ WB Guidelines ( $\left.\mathrm{n}_{56}\right)_{26}$.

153 ibid 42.

154 See eg Rumeliv Kazakhstan (n 61) paras 803-04; Burlington Resources, Inc v Rep of Ecuador, ICSID Case No ARB/o8/5, Decision on Reconsideration and Award (7 February 2017) (Burlington Award) para 299.

155 Marboe (n 13) 47. See also McLachlan, Shore and Weiniger (n 76) 423 ('[a]ny Tribunal rejecting the DCF methodology in an appropriate case would be moving away from the best practice of business and economics'). 
until very recently tribunals had tended to severely restrict it, ${ }^{156}$ also in the name of the principle against the recoverability of speculative loss. ${ }^{157} \mathrm{In}$ other words, that principle was no longer thought to contradict the very use of DCF (as suggested in Amoco), but it was nevertheless understood to set restrictive conditions for tribunals to be able to rely on it. As a result, its application was dependent not only on the investment qualifying as a going concern, but also on it possessing a track record of several years of profitability. This was also the position taken by the World Bank's Guidelines. ${ }^{158}$

More recently, this cautious approach has come under fire, precisely because it does not conform to the wider use of DCF by real-life investors. As Kantor explains, DCF is employed in financial practice to value any going concern, i.e. one that is not at risk of shutting down completely, regardless of whether it has already succeeded in generating profits. ${ }^{159}$ The absence of a track record of profitability does not mean that there will not be one in the future, as the early history of any of today's most successful ventures shows. Moreover, uncertainty about future cash flows is said to be no reason to avoid the DCF method, since that uncertainty can be factored in via the discount rate, as real investors do to determine the cost of capital. ${ }^{100}$ The legal notion of 'speculation' should simply not be an obstacle to the use of economically-informed valuation practices. ${ }^{161}$ On this basis, many have been critical of the restrictions placed on the use of DCF by arbitral tribunals, and have called on them to align with the practice of businesses. As it has been put, arbitrators must approach valuation 'in the same way as a buyer or seller would'. ${ }^{162}$ Commenting on the Tecmed case, two authors observe that 'it is one of the puzzling aspects of contemporary investment arbitration practice that tribunals have repeatedly resisted

\footnotetext{
156 ARSIWA (n 43) art 36, Comm para 26.

157 Asian Agricultural Products Ltdv Sri Lanka, ICSID Case No ARB/87/3, Award (27June 199o) para 103; Southern Pacific Properties (Middle East) Ltd v Arab Rep of Egypt, ICSID Case No ARB $/ 84 / 3$, Award (2o May 1992) para 188; Wena Hotels Ltd $v$ Arab Rep of Egypt, ICSID Case No ARB $/ 98 / 4$, Award (8 December 200o) paras 123-24; Metalclad Corp v United Mexican States, ICSID Case No ARB(AF)/97/1, Award (30 October 2001), paras 120-21; Técnicas Medioambientales Tecmed, SA v United Mexican States, ICSID Case No ARB(AF)/oo/2), Award (29 May 2003) para 186.

$15^{8}$ WB Guidelines ( $\left.\mathrm{n}_{56}\right)_{42}$.

159 Kantor (n 3) 95.

160 Cohen Smutny (n 41) 13; Philip Haberman and Liz Perks, 'Overview of Methodologies for Assessing Fair Market Value' in Trenor (n 4); Manuel A Abdala, 'Key Damage Compensation Issues in Oil and Gas International Arbitration Disputes' (2009) 24 Am U Intl L Rev 539, 551; Friedland and Wong (n 125) 430.

161 Simmons (n 136) 233.

162 Wöss and others (n 3$)$ para 6.13 .
} 
a method nearly universally recognised in the economics community as the most reliable way to estimate the [FMV] of ongoing concerns. ${ }^{163}$

The more recent case law seems to advance in that direction, by bringing the perimeter of DCF in ISDS even closer to the one found in finance. As a result, the legal limit on speculative losses is replaced by the merely evidentiary problem of establishing prospects of future profits. ${ }^{164}$ In Bear Creek $v$ Peru, for instance, even though the Tribunal still insisted that the DCF method is not appropriate when the project's future viability is still too 'speculative and uncertain,'165 there is no longer any insistence on proof of a track record of a certain period of profitability. The decisive criterion is therefore whether a hypothetical buyer would have treated the investment as a going concern. In that case, the answer was negative because it was highly doubtful that the mining project at stake would have managed to obtain the necessary permits and authorisations. ${ }^{166}$ In other cases, however, this liberal approach to DCF, more closely aligned with finance, has resulted in the tribunal relying on the method where previously it would have been rejected. In $S D$ Myers, for instance, the Tribunal noted that the absence of a track record of profitability made the application of DCF more complex, but not any less legitimate. Other tribunals have insisted that, since the objective is to establish how the market would value the investment, ${ }^{167}$ what counts is whether a potential buyer would judge it probable that the business would be profitable in the future, even if no profits have been generated yet or even if the project has not yet been operating. ${ }^{168}$ In this vein, the Tethyan tribunal calculated damages through the DCF method for a mining project that had not yet begun running nor obtained the necessary authorisation - leading to a colossal multi-billion award. When assessing whether the project would have been considered a going concern by reallife investors, the Tribunal naturally took into account the fact that the ultimate investors, Barrick Gold and Antofagasta, are global giants of the mining

163 Jack J Coe Jr and Noah Rubins, 'Regulatory Expropriation and the Tecmed Case: Context and Contributions' in Todd J Weiler (ed), International Investment Law and Arbitration: Leading Cases from the ICSID, NAFTA, Bilateral Treaties and Customary International Law (Cameron May 2005) 597, 659 .

164 John Gotanda, 'Recovering Lost Profits in International Arbitrations' (2004) 30 Geo J Intl L 61, $100 \mathrm{ff}$.

165 BearCreekMining Corpv Rep of Peru, ICSID Case No ARB/14/21, Award (3o November 2017) para 604.

166 ibid paras 599-604. Similarly, see Bilcon of Delaware et al v Government of Canada, PCA Case No 2009-04, Award on Damages (10 January 2019) paras 276-79.

167 Rumeliv Kazakhstan (n 61) para 8o9.

168 Vivendi v Argentina (n 64) para 8.3.4; Crystallex International Corp v Bolivarian Rep of Venezuela, ICSID Case No ARB(AF)/11/2, Award (4 April 2016) para $877 \mathrm{ff}$. 
sector and possess an 'impressive experience.'169 The investors' own willingness to invest considerable funds into the project is therefore treated as strong evidence that it ought to be valued as a going concern, justifying that damages be based on its future profitability rather than the costs already incurred.

On this basis, it can no longer be said that DCF is in any way exceptional. A majority of awards now rely on this method to quantify compensation/ damages owed by the State. ${ }^{170}$ The main reason is the perceived nature of valuation as essentially economic, which pushes tribunals and scholars to close the gap with financial practice and expertise. As noted approvingly: 'The general trend in favour of the DCF method is consistent with principles of modern finance.' ${ }^{\prime 71}$ The Tethyan award is probably the best and most extreme example of this tendency to replace legal authority with deference to economics, particularly how it justified its unprecedented decision to adopt a somewhat different version of the DCF method ('modern DCF', which there is no need to explain here). Against the State's objection that this variant had never been approved before in arbitral practice, the Tribunal argued that this was ultimately irrelevant: 'the absence of investment treaty jurisprudence - affirmative or negative - does not in itself constitute a valid ground for rejecting a valuation method if the Tribunal is otherwise convinced that it is sound to apply it in the present case. As valuation practices for mineral properties develop in the industry itself, the assessment of damages may likewise evolve in investment treaty arbitration'. ${ }^{172}$

\section{Challenging the Consensus: The Legal Construction} of Compensable Harm

We have seen in Section 2 that the current practice around the calculation of compensation/damages is built on a consensus around three key ideas: the universality of the standard of full compensation/reparation, the objectivity of that standard, and the economic nature of valuation. These ideas in coalition serve to present the reasoning of arbitrators on quantum issues as devoid of

\footnotetext{
169 TCC v Pakistan (n 7) para 332.

170 See PwC (n 7) (noting that, whereas pre-20oo only $17 \%$ of awards relied on DCF, the percentage climbed to $69 \%$ in the period $2011-2015$, a trend that continued later: $\mathrm{PwC}$, 'International Arbitration damages research - 2017 update').

171 Simmons (n 136) 233. Similarly, see Novenergia II - Energy \& Environment (SCA), SICAR $v$ Kingdom of Spain, SCC Case No o63/2015, Final Award (15 February 2018) para 818 ('DCF-valuation is based on fundamental principles of economic and finance and is regarded by many as the preferred method for valuation of income-earning assets').

172 TCC $v$ Pakistan $\left(\mathrm{n}_{7}\right)$ para 360.
} 
any form of judgment, whether that judgment may involve politics, equitable considerations or the interpretation of legal standards. By extension, they serve to shield the practice of arbitral tribunals from meaningful criticism: to the complaint that awards are reaching colossal heights, the response is that arbitrators have no choice but to award such amounts, since that is the objective reality of the loss suffered by investors. In other words, it is what it is.

And yet, it need not be so. In what follows, we will see that quantum calculations are not reducible to pure assessments of facts. This is so, essentially, because the harm that the principle of full compensation/reparation seeks to 'fully' undo is in itself a legal construction - the legal construction of compensable harm. As such, this notion is necessarily contingent, and reflective of a variety of considerations, including some idea about the interests that international investment law seeks to protect. Up to now, discussions on this issue have tended to assume that the notion of harm is uncontroversial, to focus only on the fullness of the extent of the obligation to compensate. Our key contention in this Section is that we need to take seriously the idea that international investment law only seeks to redress losses that it chooses to treat as compensable, and that this notion is entirely constructed rather than resulting from objective necessity. This realisation is essential, inasmuch as it challenges the key ideas on which the current approach to quantum is based: it renders banal any supposed consensus on a standard of full compensation/reparation (since such a standard does not address the more important question of what it is that needs to be fully compensated), it directly undermines the alleged objectivity of that standard (given that the construction of the notion of compensable harm necessarily reflects a variety of factors, including perceptions of what is fair or useful), and it questions the need to defer to economics or finance (since economics is not particularly well placed to determine how compensable harm should be defined).

In order to demonstrate that the calculation of compensation/ damages in international investment law is ultimately based on a constructed notion of compensable harm, we will proceed as follows. First, we will focus on the more obvious ways through which investment tribunals currently engage in the complex operation of identifying the losses that should be treated as giving rise to an obligation to compensate, in order to emphasise, often through parallels with private law, ${ }^{173}$ how the notion of compensable harm is analytically

173 As Julian Arato, 'The Private Law Critique of International Investment Law' (2019) 113 AJIL 1 has shown, private law can provide a rich source of critique for international investment law. This should not however be seen as a move to equate investor-State relations to those between purely private parties. 
much more useful than that of full compensation/reparation (3.1). Second, we will see however that the bulk of this work of constructing compensable harm is done by tribunals and commentators in a somewhat covert way, through discussions and decisions about how valuation should be performed (3.2).

\subsection{From Full Compensation to the Construction of Compensable Harm}

As we saw earlier, a key assumption around the current understanding of quantum issues is that the application of the standard of full compensation/reparation turns the quantum assessment into a purely factual enquiry. This assumption has justified a minimal role for equitable judgment and broad deference to economic and financial expertise. Against it, we will argue that law does not end with the decision to apply the standard of full compensation/reparation. Our essential contention is that implicit in any application of that standard is an additional judgment about what harm is compensable, i.e. the extent to which any negative impact suffered by the investor deserves legal protection through the award of compensation/ damages. In other words, the harm that must be fully compensated is not a brute fact, but a contingent legal construct.

To put this rather abstract idea into a more concrete perspective, let us turn to private law. In common law systems such as the English law of torts, where each tort is governed by its own specific regime, it is for example recognised that, for a claim in the tort of negligence to succeed, the claimant must have suffered a harm that the law recognises as 'actionable'. While the legal notion of 'actionable damage' is hard to define in English law, it is said to necessarily involve some kind of impairment of a protected interest that is more than negligible. ${ }^{174}$ This already suggests that determining the extent of a loss and calculating compensation is not seen as a solely factual enquiry. Civil law systems, however, are more illustrative for our purposes, since tort law there, similarly to international law, tends to be governed by a general maxim of full compensation that applies across the board. In French law, any tort law textbook will begin discussion of damages by pointing out, much like in investment arbitration, that the victim is entitled to be 'fully' or 'integrally' indemnified for its loss ('réparation intégrale'), and that identifying the extent of that loss is a purely factual assessment that rests with lower-level courts. It has however been widely recognised among commentators of French law that the idea of 'réparation intégrale' is a 'myth' and nothing more than a vague aspiration, as in practice the calculation of damages comes to reflect the

174 Michael Jones and Anthony Dugdale, Clerk and Lindsell on Torts (23rd edn, Sweet and Maxwell 2020) para 8-05. 
reprehensibility of the conduct of the tortfeasor as much as the extent of the loss. ${ }^{175}$ More fundamentally, it is also ultimately unhelpful, since any principle of full compensation hinges on a prior decision as to what losses ought be fully compensated for. ${ }^{176}$ As a result, scholars distinguish between the mere fact of a loss ('dommage'), and one that is also an injury to a protected interest and thus generates an obligation to compensate ('préjudice'). ${ }^{177}$

Why is this of any relevance to international investment law? Our contention is that the idea of full compensation/reparation is, in this context, just as unhelpful and misleading as it has been shown to be in private law ${ }^{178}$ - a 'mantra', as aptly described by Ratner. ${ }^{179}$ Rather than seeking to return the investor to a non-breach scenario, it is more accurate to speak here of an obligation to compensate for injuries to certain protected interests. Defining what kind of losses come under that protection and should therefore qualify as compensable harm typically reflects a variety of recurring considerations, of which we will focus for now on four (again with brief illustrations drawn mainly from English and French private law): first, the idea that compensable harm should be limited to normal harm; second, the idea that compensable harm ought to reflect the level of wrongfulness of the harmful action; third, the idea that compensable harm should be limited to losses of a sufficient level of certainty; and fourth, the idea that some kinds of losses, because of their nature, should be less compensable' than others (i.e. subject to stricter regimes). We will also see that these considerations are just as relevant to international investment law, inasmuch as they contribute to the legal construction of a notion of compensable harm that is specific to this area, as developed through the arbitral case law.

First, it is well-known that some idea of normality is often present in legal standards, where they seek to capture what can usually be expected of individuals or is considered to be the habitual course of events. That idea of normality is present not only in the definition and interpretation of what duties are binding, but also in the assessment of what type of losses should qualify as compensable. The doctrine of causation is the most obvious example. Indeed,

175 Olivier Moréteau, 'Basic Questions of Tort Law from a French Perspective' in Helmut Koziol (ed), Basic Questions of Tort Law from a Comparative Perspective (Jan Sramek Verlag 2015) 3, $86 \mathrm{ff}$.

${ }_{17} 6$ Vincent Heuzé, 'Incertitudes et réparation des dommages' in Le traitement juridique et judiciaire de l'incertitude (Dalloz 2008) 97.

177 See eg Philippe Brun, 'Personnes et préjudice' (2003) 33 Revue générale de droit 187.

178 Yves-Marie Laithier, 'Les règles relatives à l'évaluation du préjudice contractuel (droit anglais, droit français, droit suisse)' (2015) Revue de l'arbitrage 361, 363-64.

179 Ratner ( $\left.\mathrm{n}_{5}\right) 24$. 
legal systems everywhere recognise that certain kinds of injury that have in fact been caused by a wrongful action should not nevertheless be compensated because they are not sufficiently 'proximate.'180 The doctrine of 'remoteness' as a limit on compensation, as found notably in tort and contract law, can obviously not be reduced to a pure fact - it involves a judgment about the reasonableness of blaming the author of the breach for consequences that are in some way unusual or abnormal. ${ }^{181}$ This doctrine thus serves to separate losses that the victim will be compensated for from those that he or she will not be able to claim protection for, depending on how normal is the loss as a consequence of the breaching conduct.

A similar idea can be found in international investment law. As is wellknown, the investor may not claim damages for losses whose causal connection with the State breach is somewhat removed or unusual - losses that will in that case be referred to as 'indirect' or 'remote'. 182 This is obviously a challenge to the idea of 'full' reparation or of making the victim 'whole' again, since the tribunal is instead called upon to exclude certain losses as non-compensable because their unusual quality somehow makes it unfair to have the State carry the risk of their realisation. Eloquently, the Teinver $v$ Argentina tribunal considered that it would be 'disproportionate' to have the State pay for 'indirect or remote' damage. ${ }^{183}$ Such a reference to the idea of proportionality, which necessarily involves some kind of judgment as to the fairness of attaching a particular legal remedy to a particular instance of wrongful conduct, obviously does not fit well with an understanding of restitutio in integrum as an objective measure whose application is reducible to fact-finding.

Secondly, it is also common to adjust compensation depending on the wrongfulness of the action that led to the harm. The more reprehensible the breach, the more expansive will be the definition of compensable harm. Thus, for instance, consequential losses are frequently not compensable, but they may become so where the tort is an intentional one. This reflects the obviously greater reprehensibility of intentional torts vis-à-vis merely

180 On the distinction between 'causation in fact' and 'causation in law' (or 'proximate causation'), see Michael Moore, 'Causation in the Law' in Edward N Zalta (ed), The Stanford Encyclopedia of Philosophy (Metaphysics Research Lab 2019).

181 The classic English law cases are Hadley $v$ Baxendale (1854) 9 Exch 341 (in contract law) and Overseas Tankship (UK) Ltd v Morts Dock and Engineering Co Ltd (Wagon Mound No. 1) [1961] AC 388 (in tort law).

182 ARSIWA (n 43) art 31, comm para 10; Biwater Gauff (Tanzania) Ltd $v$ United Republic of Tanzania, ICSID Case No ARB/o5/22, Award (24 July 2008) para $784 \mathrm{ff.}$

183 Teinver SA, Transportes de Cercanías SA \& Autobuses Urbanos del Sur SA v Argentine Rep, ICSID Case No ARB/og/1, Award (21 July 2017) para 1089. 
negligent ones, and it is therefore not surprising to find this distinction in a variety of legal systems. For instance, under both English ${ }^{184}$ and French law, ${ }^{185}$ fraudulent misrepresentation entitles the victim to damages for unforeseeable losses, which otherwise would remain non-compensable.

In international investment law, the distinction between lawful and unlawful expropriation shows that ideas of wrongfulness also play an important role in the construction of the notion of compensable harm in that context. It would seem consistent with the idea of full compensation/reparation as an objective measure, that the actual amount of money to be paid to the investor would be the same in both cases. After all, the fact of the loss suffered by the investor is the same in both cases - the total deprivation of its property. In reality, however, the idea has become established that there should be a difference. ${ }^{186}$ Tribunals will often consider that the victim of an unlawful expropriation is entitled to damages for two additional items that would otherwise not be compensable: the first is the loss of any increases in value up to the date of the award, and the second is consequential losses. ${ }^{187}$ This is again contradictory with an understanding of full compensation/reparation as an objective measure - if that were so, the quantum ought to be the same regardless of the nature of the expropriation. Instead, the distinction reflects the greater level of reprehensibility that international investment law directs against unlawful expropriations, leading to an expanded notion of compensable harm. ${ }^{188}$

\footnotetext{
184 Derryv Peek (1889) 14 App Cas 337.

185 French Civil Code art 1231-3.

186 Charles N Brower and Michael Ottolenghi, 'Damages in Investor-State Arbitration' (2007) 6 TDM (distinction is 'necessary and logical'); Marboe (n 3) para 3.81 (distinction a matter of 'principle'); Derek W Bowett, 'State Contracts with Aliens: Contemporary Developments on Compensation for Termination or Breach' (1988) 59 BYIL 49, 61 (it would 'offend common sense' to fail to distinguish).

187 See generally Ratner ( $\left.\mathrm{n}_{5}\right)$.

188 As argued by Ratner ( n $_{5}$ ) 47, calibrating damages according to the severity of the violation does not necessarily involve a punitive element. We disagree however with that author's contention (held also by others) that the principle of full reparation necessarily involves setting the date of the award as the valuation date, since this 'reflects the reality that the loss is ongoing until the date of the award' (ibid 39). In reality, that date is necessarily arbitrary since the investor will also have been deprived of any increases in value that happen after the award. This does not however mean that valuation at the expropriation date provides the only 'true' representation of the loss suffered by the investor. That loss is the fact of being deprived of an investment whose value will inevitably fluctuate with the market. Fluctuating value is simply a necessary aspect to any investment. Any valuation date will therefore be arbitrary, which means that establishing the proper date will involve a variety of equitable or policy considerations: see Heuzé (n 176).
} 
Third, it is again usual for legal systems to place some limits on the recoverability of a loss, where its realisation is somewhat uncertain - for reasons of morality or policy or other. In French law, for instance, only losses that are 'certain', as opposed to merely 'hypothetical', are compensable. ${ }^{189}$ In English law, the doctrine of remoteness serves to limit damages for loss of future profits to those that are reasonably foreseeable, thus excluding compensation for the loss of extraordinary profits. ${ }^{190}$ The difficulty of dealing with uncertainty is also manifest with regards to the loss of chance. It is obvious that, no matter how minute, every chance has an economic value, which means that its disappearance will be a loss to whoever would have benefited from it coming to pass. Nevertheless, different legal systems take very different positions to determining whether the loss of chance is compensable and if so under what conditions. ${ }^{191}$ International investment law is no stranger to the problem of uncertainty as a limit on compensable harm, as attested by the continuing validity of the principle that forbids compensation for the loss of speculative profits. Indeed, even though this principle has lost much of its potency (since, as illustrated earlier, it is no longer understood to restrict the relevance of the DCF method), tribunals nevertheless continue to treat it as a valid norm and use it to exclude the recoverability of the loss of certain prospects of gain. ${ }^{192}$

Finally, legal systems may construct compensable harm, not simply by placing limits on the kind of losses that qualify as compensable, but also by enforcing a less demanding duty of conduct where the nature of the harm is thought to be less deserving of protection. Thus, so to speak, certain losses become more easily compensable than others. The best example is found in common law systems, where pure economic loss is subject to stricter conditions of compensability than personal injury. ${ }^{193}$ In investment arbitration, this idea is present in the distinction between purely financial and moral damages, since the latter are compensable only if the State's breach meets the particularly high threshold of being 'malicious and, therefore, constitutive of a fault-based liability'.194

189 Moréteau (n 175) 56.

190 Victoria Laundry (Windsor) v Newman Industries [1949] 2 KB 528.

191 Jean-Sébastien Borghetti, 'L'évaluation du préjudice en cas de perte de chance' (2015) Revue de l'arbitrage 395; Rui Cardona Ferreira, 'The Loss of Chance in Civil Law Countries: A Comparative and Critical Analysis' (2013) 20 Maastricht J Eur \& Comp L 56.

192 See eg Burlington v Ecuador (n 154) para 281.

193 As stated by Lord Steyn in the House of Lords case White $v$ Chief Constable of South Yorkshire [1999] 2 AC 455, 492: '[ $t$ ] he contours of tort law are profoundly affected by distinctions between different kinds of damage or harm'.

194 Desert Line Projects LLC v Rep of Yemen, ICSID Case No ARB/o5/17, Award (6 February 2009) para 290. 


\subsection{The Construction of Compensable Harm Through Valuation}

We have just seen various ways through which arbitral tribunals distinguish the mere fact of a loss suffered by an investor from legally compensable ones, i.e. those that are legally protected. We submit, nevertheless, that some of the most important aspects of the construction of compensable harm are not addressed directly in the current practice of investment arbitration, but implicitly through the valuation process.

Valuation refers to the process whereby the worth of a certain asset is estimated. In legal adjudication, valuation serves to translate a loss that is legally compensable into a monetary equivalent. Logically, it should take place once the standards of compensation, including the legal definition of compensable harm, have been appropriately interpreted and applied, and should be coherent with that prior determination. In practice, though, the two stages are difficult to distinguish. ${ }^{195}$ Thus, the process of valuation can serve to define what it is that is being valued: as put by the sociologist Liliana Doganova, 'Statements about how much things are worth are statements about what things are, or what they should be'.196 This is particularly true in current arbitral practice, where one can observe a certain reversal: the limits of compensable harm are defined through valuation, rather than the other way round. ${ }^{197}$ It is for this reason that Sornarajah is right to warn against claims about investor rights being made via the 'back door' of valuation. ${ }^{198}$

We will examine three main examples of how compensable harm is defined in investment arbitration, somewhat covertly, through the process of valuation. First, the choice of valuation method, and in particular the preference for DCF, has served to expand the compensability of the loss of future profits (and thus, the extent to which future profitability is a protected interested under international investment law) (3.2.1). Second, the choice of the appropriate basis of value serves to limit compensation/damages to losses that are thought to be 'normal', much like the doctrine of causation (3.2.2). Third, the construction of the market on which the FMV standard is based, which is largely a fictional one, determines the 'but-for' scenario to which the investor must be returned to via a monetary award (and thus again serves to define the losses for which the investor is entitled to compensation) (3.2.3).

\footnotetext{
195 Jarrosson (n 18) $35^{\circ}$.

196 Doganova (n 139) 6.

197 Desierto (n 5 ) 442 (observing that tribunals tend to jump straight to valuation issues without pausing enough to consider the appropriate standard of compensation).

198 Sornarajah $\left(\mathrm{n}_{3} 6\right) 532$.
} 
It is submitted, first of all, that the discussion around valuation methods more often than not should be properly understood as a discussion around compensable harm. In particular, the rise of the DCF method has served to expand massively the extent to which investors are entitled to compensation/ damages for the loss of future profits. Where traditionally the expectation of future profitability was often not seen as a protected interest or only under very strict conditions, currently the international investment law system generally works to protect that expectation very robustly. It is of course true, as we have insisted, that the rise of the DCF method has not been discussed in these terms, as related to the scope of compensable harm, but instead in the language of economics or finance. We shall argue, nevertheless, that the alleged need to defer to non-legal realities only serves to hide the truly fundamental issue at stake, namely the extent of the investor's entitlement to protection for the loss of future profitability.

The fact that the question of valuation is increasingly approached as economic rather than legal is, of course, key. This is the reason why the DCF method is thought to be appropriate for going concerns, whereas investors will only recover the costs incurred in other cases - it is because this is the position that is thought to match that of the financial community. It is also for this reason that Judge Brower and later many commentators have accused the Tribunal majority in Amoco of 'misunderstanding economics' - on the assumption that the majority was indeed purporting to reason in economic terms, and should have been reasoning in those terms. That is not, however, what the majority was doing in that case, nor should it necessarily have done - and herein lies the fallacy of that critique of Amoco. Instead, it was attempting to define the extent of the loss that the victim could legitimately expect to recover in monetary equivalent under the applicable legal regime. On this basis, it came to the conclusion that the compensability of the loss of future profitability should be subject to very strict conditions. There is no reason to assume that, in that determination, considerations other than those that derive from economics or finance are irrelevant. In fact, as we pointed out earlier, every chance has an economic value, but legal systems everywhere choose to limit claims for the loss of expectations to some uncertain gain, for reasons that cannot be reduced to economics - exactly as the Amoco majority purported to do.

Thus, the affirmation of the exclusively economic nature of value and valuation in the context of investment arbitration is, in reality, hiding a different claim: that non-economic considerations may not legitimately interfere with 
the determination of the compensable harm for which the investor is entitled to compensation/damages. It is thus very much a normative claim, and one whose justification is none too evident. In other words, the tendency to rely on DCF more and more frequently should not be understood as a mere reflection of financial practice and expertise. It should instead be seen, more broadly, as a judgment about compensable harm: where previously it tended to be considered that the victims of a State breach were only entitled to recover the costs incurred or had only a very limited claim to future profits, the current position is that the expectation of future profitability is generally a protected interest. To speak in the terms of the traditional debate on the appropriate measure of damages for a breach contract, ${ }^{199}$ there has been a shift in international investment law, from protecting the reliance interest, to guaranteeing instead the expectation (or performance) interest. ${ }^{200}$ There may obviously be good reasons (or not) for such a shift, but they cannot be said to derive from facts alone, nor from a hollow appeal to full compensation/reparation.

This discussion also serves to challenge a related key fallacy underlying Judge Brower's critique of the Amoco majority. It is the idea of a neat separation between law and economics: the former defines the conditions that trigger the State's liability (e.g. for expropriation) and the applicable standard of compensation (e.g. full compensation), whereas the latter serves to establish the fact and magnitude of the investor's loss (and thus the amount of money necessary to compensate it). In reality, however, the two are in 'tension', as observed by Zarbiyev ${ }^{201}$ - economics may clash, at the normative level, with legal standards or principles. Indeed, recourse to economics is serving to reconfigure the losses that are treated as compensable under international investment law: where previously traditional legal principles heavily restricted the ability to claim compensation/damages for the loss of future profitability, now the norms of economics have justified a huge expansion of that claim. There is nothing surprising about this normative conflict between law and economics: despite influential claims to a clear division of labour between the two, the

\footnotetext{
199 As laid out in the famous article: Lon Fuller and William R Perdue, 'The Reliance Interest in Contract Damages' (1936) 46 Yale L J 52, 373.

200 On the use of this distinction in investment arbitration, see David A Collins, 'Reliance Based Remedies at the International Center for the Settlement of Investment Disputes' (2009) 29 Nw J Intl L \& Bus 195; Paulsson (n 95).

201 Zarbiyev (n 132) 375.
} 
conflict is particularly well documented in legal areas that are heavily infused with economic thought, such as competition or financial law. ${ }^{202}$

\section{2 .2}

\section{The Choice of FMV as Basis of Value to Define Normally}

\section{Occurring Losses}

Beyond causation, with which we dealt earlier, an idea of normality also makes its way into the assessment of compensation/damages through a less obvious path, that of the selection of FMV as the basis of value employed by tribunals.

In private law, there is a general discussion with regards to the level of abstraction with which the harm of the victim should be evaluated. Should it be by reference to the victim's concrete situation? Or should the judge refer instead to an abstract standard, based on some idea of normality? To take the example of compensation for loss of future earnings following a road accident that leaves a child paralysed for life: should compensation for loss of future earnings be based on that child's concrete prospects, taking into account all individual circumstances, or should it be based instead on average earnings, say at a national level? There is no obvious answer to these questions - different legal systems offer different combinations of these approaches or leave it to the judge to decide on a case by case basis. ${ }^{203}$ Once again, though, a decision needs to be made, one that cannot be deduced from any principle of restitutio in integrum.

The same discussion is present in international investment arbitration, even if it focuses on the selection of the appropriate basis of value. Some authors have insisted that the losses resulting from a treaty breach ought to be identified from a 'subjective' or 'concrete' perspective, i.e. by reference to the particular situation of the specific investor. ${ }^{204}$ Thus, so goes the argument, tribunals ought to rely, not on FMV, but on alternative bases of value from the accounting/financial world such as 'fair value' (i.e. the price at which two concrete parties would be estimated to transact) 205 or 'investment value' (i.e. the value of an asset to a concrete individual, be it its owner or another party). ${ }^{206}$

\footnotetext{
202 On the tension between law and economics as competing sets of norms, see the insightful theory of economic transplants developed by Katja Langenbucher, Economic Transplants: On Lawmaking for Corporations and Capital Markets (CUP 2017).

203 Heuzé (n 176).

204 Marboe (n 1).

205 Fair value can be defined as 'the estimated price for the transfer of an asset or liability between identified knowledgeable and willing parties that reflects the respective interests of those parties': Alberro (n 49) 10.

206 Marboe (n 3) para 4.54.
} 
Consequently, it is said that tribunals ought to pay attention to the particular advantages that a specific investor may draw from a specific investment (e.g. in terms of 'synergies with other operations owned or controlled'), ${ }^{207}$ as well as to evidence of that investor's subjective appreciation of the investment's worth (e.g. its own projections of future revenue, whether they coincide or not with those of the market). ${ }^{208}$ In general, however, tribunals have not been persuaded by this position. The case law has failed to accurately distinguish investment value from $\mathrm{FMV},{ }^{209}$ and has stuck to the latter as the proper basis of value - which can be said to be 'abstract' or 'objective' since it is not tied to the particular situation of the investor but is instead based on general market perceptions. Even where an arbitral tribunal has affirmed the need for a subjective approach to the calculation of damages, it has nevertheless ended up relying on FMV. For instance, the Murphy $v$ Ecuador tribunal stated that the investor should be entitled to damages equal to the 'concrete and actual damage incurred', ${ }^{210}$ but later based the calculation on FMV as 'the commonly accepted standard for calculating damages ... [u]nder customary international law'.211

The decision to opt for such an 'impersonal'212 approach to the quantification of damages is not usually justified, but contributes decisively to define the losses that can be said to be compensable. Indeed, investors will only be able to claim damages for losses that are normal, by reference to FMV as a reflection of normality. Any losses beyond that standard will be excluded as non-compensable. This approach probably has to do with the practical advantage and related predictability of avoiding having to measure the somewhat elusive subjective perceptions of the investor, ${ }^{213}$ or with a vague notion that it is unjust to reward the overly optimistic investor or punish those that are more conservative. What is clear, in any case, is that the decision to forego a more concrete basis of value cannot be reduced to the assessment of the facts, and involves instead a judgment about which interests are protected under international investment law.

\footnotetext{
207 Marboe (n 1$) 729$.

208 ibid.

209 Marboe (n 3) paras 4.59, 7.13.

210 Murphy Exploration \& Production Co International v Rep of Ecuador, PCA Case No 2012-16, Partial Final Award (6 May 2016) para 425.

211 ibid para 482. Similarly, Teinver $v$ Argentina (n 183) paras 1033, 1089.

212 Merrill (n 110) 119.

213 Ratner ( $\left.\mathrm{n}_{5}\right) 41$.
} 


\subsubsection{A Fictional Market as the But-For Scenario}

The content given to the FMV standard is key since it serves to define, in the terms of a monetary equivalent, the but-for scenario or status quo ante that the investor must be returned to. This is a key aspect of the construction of compensable harm, since it is by defining what it is that the investor had prior to the breach, that tribunals ultimately determine what it is that it lost and can therefore claim compensation for.

As we have explained earlier, it is commonly assumed that determining the FMV of an investment at any particular time is, in itself, nothing more than a fact-finding operation, supported by economic expertise. The key point here will be to offer a response to that claim. We will show that the FMV standard consists in a legally constructed 'fiction'214 or 'myth':215 FMV is assessed in investment arbitration as if not only a market actually existed where the investor would have been able to exchange its investment for a sum of money (even though such a market often does not exist), but also on the assumption that this market possesses certain idealised characteristics. In this way, the legal interpretation of FMV serves to construct a fictional butfor scenario ${ }^{216}$ - and thus leads to, somewhat paradoxically, allowing investors to obtain via remedies what they could not have obtained had the State not breached its obligations. In no other instance is the legally constructed nature of compensable harm in international investment law so manifest, as the loss on which compensation/damages are based is here entirely manufactured.

First of all, tribunals tend to refuse to take into account certain risks that real-life investors do consider relevant (as value-depressant), on the basis that investors should not legitimately have to bear them. An example is found in Occidental $v$ Ecuador, where the Tribunal refused to refer in its valuation to the price that the investor had previously obtained for selling part of its participation in the oil concession, on the ground that the price reflected the risk that the State may later decide to terminate the said concession. The Tribunal thus decided that this was a risk that the investor should not have to bear, even though actual investors such as the claimant itself had considered it relevant to fixing the price of a real-life transaction. ${ }^{217}$

Most commonly, this sort of reasoning arises in relation to so-called country risk. This refers to the higher probability that the profits obtained by the investor will be less than expected, because of the greater political, economic,

\footnotetext{
214 Merrill (n 110) 116.

215 Girvan (n 26) 166.

216 Wöss and San Román (n 120).

217 Occidental $v$ Ecuador (n 10) para $779 \mathrm{ff}$.
} 
financial, or cultural instability that is particular to the country where the investment has been made. ${ }^{218}$ The general trend among tribunals (although there are some exceptions $)^{219}$ is to consider that only part of the country risk should be computed within a DCF calculation. In particular, it should not include the more specific risk that the State may adopt unilateral measures in breach of the applicable investment treaties. ${ }^{220}$ Such a position is commonly justified as necessary to disincentivise unlawful State conduct. ${ }^{221}$ The point is not here to discuss whether such an approach to country risk is justified. We wish instead to insist on the fact that it creates a further gap, to the benefit of investors, between the FMV, as a standard on the basis of which damages are calculated, and a real-market assessment of risk. The former cannot therefore be said to be an 'empirical observation,',222 but is instead a (legal) construct, whose elaboration by tribunals is motivated by a variety of concerns. ${ }^{223}$

Such a gap is even more evident, however, with regards to another key assumptions on which the FMV standard: the very existence of an open and unrestricted market (and thus the investor's ability to convert its investment into money). According to the International Glossary of Business Valuation Terms published by the American Society of Appraisers, FMV is defined as 'the price, expressed in terms of cash equivalents, at which property change hands between a hypothetical willing and able buyer and a hypothetical willing and able seller, acting at arm's length in an open and unrestricted market, when neither is under a compulsion to buy or sell and when both have reasonable knowledge of the relevant facts'. This definition has been repeatedly endorsed in the case law. ${ }^{224}$ The assumption of an 'open and unrestricted market', however, clashes with real-life conditions, where various restrictions prevent or

218 Marcos D García Domínguez, 'Calculating Damages in Investment Arbitration: Should Tribunals Take Country Risk into Account?' (2016) 34 Ariz J Intl \& Comp L 96.

219 Venezuela Holdings, BV, et al v Bolivarian Rep of Venezuela, ICSID Case No ARB/o7/27, Award (9 October 2014) para 365; Tidewater Inc, Tidewater Investment SRL, Tidewater Caribe, CA, et al $v$ Bolivarian Rep of Venezuela, ICSID Case No ARB/10/5, Award (13 March 2015) para $182 \mathrm{ff}$.

220 ConocoPhillips v Venezuela (n 7) para 9o6; Gold Reserve v Venezuela (n 108) para 841; Flughafen Zürich AG and Gestión e Ingenería IDC SA v Bolivarian Rep of Venezuela, ICSID Case No ARB/10/19, Award (18 November 2014) para 905.

221 Marboe (n 3) para 5.176.

222 Florin A Dorobantu, Natasha Dupont and Alexis Maniatis, 'Country Risk and Damages in Investment Arbitration' (2016) 31 ICSID Rev 219, 224.

223 Wöss and others ( $\mathrm{n}_{3}$ ) para 6.36 (arguing that FMV, in contrast to mere market value, should be determined by reference to normal market conditions, in order to 'prevent governments from taking advantage of market crisis to expropriate cheaply').

224 See eg CMS $v$ Argentina (n 101) para 402. 
make it difficult for the holder of an asset to convert it into money. Indeed, it is often the case that there is simply no market for the asset in question. This may derive from its intrinsic uniqueness, but sometimes it has to do with legal limitations on the ability of the investor to sell under the applicable domestic legislation.

Tribunals, however, have tended to ignore such real-life restrictions, and valued the investment as if its unimpeded marketability was a given. For instance, to return to the Occidental $v$ Ecuador case, ${ }^{225}$ the oil concession that had been awarded to the investor could not legally be sold to any third party, per both Ecuadorian law and the concession agreement, without seeking first the discretionary approval of the competent authorities. This was nevertheless not seen as an obstacle to the application of the FMV standard - as noted earlier, it is generally thought that FMV can be determined even where there is no market. 226 The Tribunal did not therefore adjust its calculations to take this legal restriction into account. An even more illustrative example is the case of Koch $v$ Venezuela. Relying on the definition of FMV as an 'open and unrestricted market', the claimant did not only push against any discounts to account for restricted liquidity, but argued moreover that compensation should be adjusted upwards to eliminate the liquidity restrictions that existed under real life conditions. ${ }^{227}$ Incredibly, the Tribunal seemed to agree, without however justifying it explicitly. ${ }^{228}$

The issue with such an approach is that the ability of the owner to exchange an asset for a sum of money on the marketplace should be key to its valuation. To state the obvious: the value of an asset that can be traded without restrictions is not the same as if such restrictions existed. Marketability or liquidity, i.e. the ability to transform an asset into money, is therefore a significant component of economic value. The value given to the oil concession in Occidental $v$ Ecuador by an investor would invariably take into account the legal and contractual restrictions placed on its ability to later sell it off. Thus, and yet again,

225 OccidentalvEcuador (n 10).

226 Lieblich (n 111) 63 (arguing that DCF serves to recreate a market where there is none).

227 Koch Minerals Sàrl \& Koch Nitrogen International Sàrlv Bolivarian Rep of Venezuela, ICSID Case No ARB/11/19, Award (30 October 2017) para 9.70.

228 Recently, however, tribunals have begun considering more seriously, albeit with inconsistent results, the inclusion of illiquidity discounts to reduce damages, reflecting the additional return that an investor would require to compensate for the added risk of investing in an asset with restricted marketability as opposed to one that is perfectly marketable (the 'illiquidity premium'): see eg Novenergia $v$ Spain (n 171) para 834 (refusing to include an illiquidity discount given insufficient evidence of restricted ability to divest); Masdar Solar \& Wind Cooperatief UA v Kingdom of Spain, ICSID Case No ARB/14/1, Award (16 May 2018) para $634 \mathrm{ff}$ (accepting a discount). 
it cannot be said that FMV aims to replicate real-life conditions: it assumes that the asset or business is fully marketable - or, to put it otherwise, that it has more value than it does in reality. In fact, as Kantor observes, 'if no actual market exists and no realistic comparable or substitute is available, those circumstances may in fact signal that the market value of the relevant business is zero. ${ }^{229}$

Similarly with country risk, we can therefore see that the way FMV is interpreted and applied by arbitrators rests on a fiction, here one of unrestricted convertibility. Both fictions serve to inflate the valuation beyond the value that the investor would have been able to realise in real-life conditions. They also serve to further define compensable harm, by positing that what the investor lost and can claim compensation for, is a freely tradeable asset not subject to certain forms of risk. What, however, are the specific reasons that justify these fictions? As we saw earlier, the erasure of (at least part of) the country risk from DCF calculations is generally justified on policy grounds: the State must not be incentivised to pursue unlawful action. The assumption of unrestricted convertibility points to reasons that are harder to articulate, and yet are probably more fundamental.

Ultimately, the value-generating assumption that the investment can be freely traded evidences the extent to which arbitral tribunals are married to the idea that economic value is a fact independent from law. Arbitral tribunals estimate FMV as if this did not depend on the applicable legal environment, ${ }^{230}$ particularly the one of the host State (as in the multi-billion Occidental $v$ Ecuador award). They do so in the face of the inseparable connection, underlined by a long history of scholarship, ${ }^{231}$ between law and value. Indeed, the tribunal's own decision as to the appropriate approach to the calculation of damages will impact value ${ }^{232}$ - after all, investors everywhere will value investment projects more highly if they are confident that tribunals will, for instance, not make much use of the principle of non-recoverability of speculative profits when assessing damages. To focus nevertheless on marketability,

229 Kantor (n 3) 59.

230 Anthony Bonen, 'The Compensation Quantum in BIT Arbitration: How Economic Theory Informs the Legal Concept of Property Rights' (2009) <www.researchgate.net/ publication/263697287_The_Compensation_Quantum_in_BIT_Arbitration_How_eco nomic_theory_informs_the_legal_concept_of_property_rights> accessed 19 February 2021.

231 John R Commons, Legal Foundations of Capitalism (MacMillan 1924).

232 Akbar Rasulov, 'The Empty Circularity of the Indirect Expropriations Doctrine: What International Investment Law Can Learn from American Legal Realism' in Ugo Mattei and John Haskell (eds), Research Handbook on Political Economy and Law (Edward Elgar 2017) 371 . 
as one of several key value-generating attributes that may be bestowed upon an asset through legal means - the existence of this ability depends on certain legal institutions being in place. ${ }^{233}$ Indeed, it is only on condition that the applicable legal system allows for the asset to be legally sold, as well as the enforcement of that contract, that the asset will be convertible into money and thus valued as such. The exact extent of that ability will also be legally determined - for instance, the valuation of the asset will reflect if the sale is subject to discretionary authorisation or to a set of rigid conditions or instead practically unencumbered, whether its enforcement is made more difficult than for standard commercial transactions, etc. Tribunals have nevertheless chosen to ignore these considerations, and to approach value as somehow intrinsic to the assets in question.

We do not seek to argue that the approach of arbitral tribunals to the FMV standard has had the effect of emancipating value from any particular legal environment. On the contrary, the economic value of foreign investment is still inevitably shaped through law. The law in question, though, is a privileged regime that, hidden under the pretence of value as a pre-legal phenomenon, has been autonomously developed by arbitrators themselves, leading to a greatly expanded notion of compensable harm.

\section{4 Moving Forward: The Calculation of Compensation and Damages as an Expression of the Legitimate Expectations of Investors}

We have just exposed the extent to which current practice, even if operating under the pretence that the calculation of compensation/damages leaves little room for discretionary judgment, is in reality built upon a series of contestable choices that have served to construct a notion of compensable harm, one that is both contingent and specific to international investment law, as well as largely favourable to investors. This realisation immediately raises a series of questions, of the utmost practical importance. Indeed, as we saw in Section 2, many of the essential features of current arbitral practice (such as the centrality of the standard of full compensation/reparation, the exclusion of equitable judgment and the preference for the DCF method) are based precisely on the idea that the determination of quantum is essentially a fact-finding operation guided by economic and financial expertise. If this idea is misguided, as just

233 See Katharina Pistor, The Code of Capital: How the Law Creates Wealth and Inequality (2019) ch 1 (referring to 'convertibility' as an attribute that may be legally bestowed on an asset). 
shown in Section 3, how should arbitral tribunals approach quantum matters and the notion of compensable harm? What kind of reasoning should arbitrators develop to calculate compensation/damages, if they are to take seriously the legally constructed nature of both compensable harm and economic value?

We will now seek to provide some answers to these questions. It is important again to stress that our argument is de lege lata: we seek to show not only that current practice is incorrect as a matter of law, but also suggest how quantum should instead be calculated from that same perspective. It may well be that today's arbitral practice on this issue, grounded as it is on such a solid consensus, will not easily change course in a more appropriate direction, which would suggest the need for treaty reform. Such a treaty reform could benefit from the ideas that now follow. That is, nevertheless, a different matter from the one that occupies us: what is the legally correct way for tribunals to approach the calculation of compensation/ damages today.

To answer this question, we would like to begin with a general remark that follows from our previous critique: since full compensation/reparation is not an objective measure, there is no obvious reason why tribunals should disregard equitable considerations within their calculations, or see this question as entirely insulated from politics and discretionary judgment. It cannot therefore be ruled out that tribunals equitably consider, inter alia, the impact of the award on the finances of the State, the history of the investor's conduct, the public policy rationale of the measure in breach or the nature of that breach ${ }^{234}$ - not as exceptions to the standard of full compensation/reparation, but as relevant factors to the determination of what counts as compensable harm (i.e. that which needs to be 'fully' compensated). ${ }^{235}$

We will not, however, further develop this point, and focus instead on one specific issue - the recoverability of the loss future profits. It is one of great practical importance - in great part, it is by massively expanding the relevance to quantum calculations of the projections of the investor's future income that tribunals have facilitated the inflation of awards. Be that as it may, we have also chosen to focus on this issue as particularly illustrative of various key aspects of how tribunals should reason when quantifying compensation/damages - and most of all, the need to take seriously the notion of legitimate expectations.

234 Crespi Reghizzi (n 5) 62-63.

235 Separate Opinion by Brownlie on the Issues at the Quantum Phase, CME v Czech Rep (n 66) paras 34, 75; cfr Paparinskis (n 89) (arguing against the permissibility of 'crippling compensation, but as an exception to the principle of full reparation). 
Indeed, even though this notion is not usually seen as relevant to quantum, it is submitted that, not only is this a mistake from a conceptual point of view (the calculation of compensation/damages is ultimately a reflection of the legitimate expectations of investors), but moreover it may bring significant clarity as to how key issues of quantum should be addressed.

We will proceed as follows. We will first insist, as a preliminary matter, on the pertinence of the notion of legitimate expectations to quantum matters, showing how the calculation of compensation/damages should be approached as integral to the interpretation of the scope of the rights of investors (4.1). Secondly, we will explain how the notion of legitimate expectations can illuminate the question of whether, and if so under what conditions, investors may have a rightful claim to future profits, leading generally to the conclusion that tribunals should show much greater circumspection when awarding compensation/damages on the basis of the investor's projected profitability (4.2). Third and finally, we will argue that the notion of legitimate expectations can also help determine, where the investor is indeed entitled to such future profits, how compensation for their loss should be quantified, justifying why investors should often be able to obtain no more than a reasonable rate of return (4.3).

\subsection{The Relevance of Legitimate Expectations to Quantum Calculations}

As we have seen until now, in order to decide whether compensation/damages should reflect the loss of future profits, tribunals and commentators have tended to simply ask whether, as a matter of fact, future profitability would have been taken into account by a hypothetical investor when valuing the investment as a whole (and to conclude that, where the answer is yes, as would be the case whenever it qualifies as a going concern, an income-based valuation method such as DCF would be justified to calculate compensation/ damages).

If we accept however that the question of whether an investor can lay claim to future profits in compensation/damages calculations is not reducible to the assessment of brute facts, the problem immediately arises as to how that claim should be justified. Even though that problem is usually not addressed as a normative one, on some rare occasions, substantive arguments are more transparently articulated. It is sometimes vaguely pointed out that the whole point of the international investment regime is to favour investors. The $A I G v$ Kazakhstan tribunal, for instance, argued that: 'if foreign investment is to be encouraged (which is the avowed object of all bilateral investment treaties), the compensation-standard must be such as to ensure that investors receive at least the present value to them of the expected future earnings that they would 
derive from their investment.'. ${ }^{236}$ This argument is nevertheless weak: even if it is accepted that the goal is to encourage foreign investment, this alone cannot explain why investors should be protected to any particular extent. Others have pointed to the danger that opportunistic takings of lucrative businesses will be incentivised if the loss of future profits is not indemnified, ${ }^{237}$ but again this argument is also unsatisfactory since it does not clarify when a taking is to be judged as opportunistic (rather than, say, welfare-maximising). On the other side, the main argument against the recoverability of future profits is the traditional principle that forbids compensation for speculative losses. However, even if that principle justifies some limits on claims for future profits, it is of little use in determining the degree at which the inherent uncertainty in such claims ought to qualify as unduly speculative.

In order to identify the precise extent to which claims for the loss of future profits should be limited, it is submitted that, rather than insist on the uncertainty that comes with any such claim or engage in a ping pong debate of policy arguments, we should focus on the notion of legitimate expectations. It is common for this notion to feature in discussions around the scope of State conduct that is forbidden under the applicable investment treaty, but it is basically absent when it comes to the analysis of quantum. And yet, quantum questions are rights questions. This is nothing more than the traditional maxim that remedies precede rights: it is by deciding on how to calculate compensation/ damages that the tribunal configures the precise extent of the entitlement of investors. To speak of an investor right to be free from a particular form of State interference tells us little, without also addressing the remedies available for breach and how damages will be calculated: for instance, that right will clearly not be the same, if the interference gives rise to a claim for loss of profits and if it does not. Just as the legitimate expectations of investors are relevant to determining the scope of the conduct that the State is proscribed from engaging in, they are also relevant to determining the extent of compensable harm and thus of monetary compensation to which investors are entitled. In short, the application of the standard of full compensation/reparation cannot be divorced from an interpretation of the investor's legitimate expectations.

And yet, how can such a vague notion as that of legitimate expectations help us at all in quantum matters, and in particular to determine under what conditions the loss of future profits should be compensable? The answer is that the notion should push tribunals to establish whether the investor has an

$236 \quad A I G v$ Kazakhstan (n 59) 85.

237 Martin J Valasek, 'A "Simple Scheme": Exploring the Meaning of Chorzów Factory for the Valuation of Opportunistic Expropriation in the BIT Generation' (2007) 6 TDM. 
expectation of future profits that is protected under international investment law. Establishing the existence of an expectation is necessary, but insufficient: that expectation also needs to be a legitimate one. ${ }^{238}$ For an expectation (here, of future profitability) to be legitimate, it must be built on some basis of a particular quality. Indeed, from a general legal perspective, expectations are only legitimate if grounded on a promise or guarantee or duty that the legal system chooses to render enforceable. Take for instance the protection of the performance interest in contract law, i.e. the idea that damages for breach of contract should cover the value of what was promised by one party to another. That the performance interest is protected is not because it is predicted as a matter of fact that this promise will be fulfilled, but because legal systems attach a singular value to the respect of contractual promises, thus justifying that they give rise to concrete expectations. ${ }^{239}$ It is only because of this decision, based on a variety of considerations, that a legitimate claim to the performance interest can be said to exist. This is also why a contract may also serve to limit the legitimate expectations of parties - where the contract includes a liquidated damages clause, any claim to a higher amount will be rejected as lacking appropriate basis, even if based on an actual loss.

As Nicolás Perrone insightfully explains, there are two main theories as to the appropriate basis on which the legitimate expectations of foreign investors could be grounded in international investment law. ${ }^{240}$ The first, the most traditional and 'State-friendly', is that the basis is found in the relevant domestic law and investment contract, which will define in a relatively detailed way what specific rights are bestowed on the investor. Under this approach, international investment law does not create additional rights but only serves to guarantee the enforcement of those that derive from the law normally applicable. The alternative interpretation, the more 'investor-friendly' one, considers instead that international investment law does create substantive rights for investors. As Perrone argues, this fits better with the current state of the field, as shown in particular by the operation of the FET standard. Under the latter, certain representations by the State that under domestic law are not enforceable (e.g. of regulatory stability), will give rise to legitimate expectations and thus become enforceable via arbitration. Those representations nevertheless need to be of a

\footnotetext{
238 Legitimate expectations are often confused with the subjective expectations of the parties: see eg McLachlan, Shore and Weiniger (n 76) 429.

239 Andrea Pinna, La mesure du préjudice contractuel (LGDJ 2007) para 32 (pointing out that the notion of legitimate expectations is synonymous in contract law with the contractual content).

240 Nicolas M Perrone, "The Emerging Global Right to Investment: Understanding the Reasoning Behind Foreign Investor Rights' (2017) 8 JIDS 673, 689.
} 
certain quality - per the case law, this mostly requires that they meet a certain threshold of 'specificity', merely generic statements being insufficient. ${ }^{241}$

It is not our intention in this article to take position on this debate. All we wish to point out is that, if we take seriously the idea that claims to damages for loss of future profits are inseparable from legitimate expectations, and that such expectations need to be based on legal guarantees of some quality, we ought to turn back to either domestic law (if we take a more traditional approach to legitimate expectations) or to the standards of protection offered by international investment law itself (if we follow the more pro-investor stance that current practice reflects). We will examine in the following Sub-Section how these alternatives could help establish the compensability of the loss of future profits.

\subsection{Under What Conditions Should Compensation/Damages Reflect the Loss of Future Profitability?}

The first thing to point out is that, regardless of which of the two approaches to legitimate expectations identified by Perrone, neither of them can be said to fit with the way compensation/damages are currently calculated. To start with, it is of course true that practically no attention is paid to domestic law to calibrate the legitimate expectations of investors with regards to quantum matters. When respondents seek to rely on some aspect of their domestic legal system, tribunals tend to exclude it as wholly irrelevant - as for instance in the Masdar $v$ Spain award, where it was said that standards of compensation and methods of valuation are subject only to international law. ${ }^{242}$ In some cases, even the investment contract has been rejected as the appropriate grounding for the legitimate expectations of parties, with tribunals refusing to take into account contractual limitations on damages ${ }^{243}$ - and insisting for instance, rather dubiously, that to do so would have been akin to allowing the State to rely on its internal law to justify the non-performance of its obligations under international law. ${ }^{244}$ That said, international law is not relied on either as the appropriate source of legitimate expectations with regards to compensable harm. There is practically never any reflection on the specific interests that the relevant standards of investor protection seek to preserve, or indeed

\footnotetext{
241 See eg Continental Casualty Company v Argentine Rep, ICSID Case No ARB/o3/9, Award (5 September 2008) para 261.

242 Masdarv Spain (n 228) para 580.

243 Arato (n 173) 22-24.

244 Venezuela Holdings $v$ Venezuela (n 213) para 225. The award was later annulled precisely on this ground: Decision on Annulment (9 March 2017).
} 
consideration of any specific representations by the State that could affect the investor's legitimate expectations of future recovery.

These observations already suggest that taking seriously the idea that quantum questions are rights questions, and that the calculation of compensation/ damages should reflect the legitimate expectations of investors, will offer a direct challenge to current practice. Indeed, the problem with the latter is not only that quantum is not approached, from an analytical perspective, as a rights problem. It is also, more fundamentally, that it uses, as the ultimate criterion to identify the legitimate expectations of investors, an entirely fictional market, with diminished risk and unrestrained marketability. In other words, the current approach to compensation/damages serves to uphold a legitimate expectation to such idealised market conditions. And yet, there is no obvious basis for such a right. To award compensation on that basis is contrary to the principle, as recently put by a tribunal, that 'reparation cannot exceed the harm effectively suffered', or, in other words, that 'one cannot do better in litigation than in real life.'.25

If tribunals take seriously the idea that any claim to compensation/damages needs to be reflective of the legitimate expectations of investors, how would the two possible approaches to this notion apply? Under the first approach, the extent of the investors' legitimate expectation will be mostly defined in the legal system of the host State. In particular, it will be necessary to determine if the investment is protected under the law of property - if this is so, the claim to future profits will be strong since usually, in this area of the law, the property owner is entitled to reap its fruits. ${ }^{246}$ If the investment takes instead the form of a validly concluded contract, some measure of future benefits will also tend to be protected, ${ }^{247}$ for contract law usually protects the expectation interest (rather than merely the costs incurred in reliance on the promise). ${ }^{248} \mathrm{On}$ the other hand, the claim to future profits will be weak if no such rules are applicable. For instance, in cases involving the denial of a contract, license or authorisation to operate, domestic legal regimes will typically not recognise any entitlement to recover the profits that would have been generated had the agreement taken place, and damages will therefore be limited to

\footnotetext{
245 PV Investors $v$ Kingdom of Spain, PCA Case No 2012-14, Award (28 February 2020) para 792.

246 See eg French Civil Code art 547.

247 Sangwani P Ng'ambi, 'Permanent Sovereignty over Natural Resources and the Sanctity of Contracts: From the Angle of Lucrum Cessans' (2015) 12 Loy U Chi Intl L Rev 153.

248 See eg Robinson v Harman (1848) 1 Ex 85o (Ct of Exchequer) (English law); French Civil Code art 1149 (French law). For a comparative law analysis of the recoverability of lost profits, see Gotanda (n 164).
} 
incurred costs. ${ }^{249}$ Alternatively, under the more pro-investor approach, it will be necessary to turn to the standard of investor-protection under the applicable investment treaty that the State has violated. We would aim to conduct a more breach-based assessment of damages (against the current practice that, for the reasons already pointed out, tends to divorce the interpretation of treaty standards from quantum matters), to determine whether the standard that has been violated contains some autonomous guarantee of future profitability. ${ }^{250}$ In other words, it is indispensable that the treaty standard in question is found to protect the investor, not only from certain State conduct, but also more specifically against interference with its ability to capture profits that the investment is expected to generate. For instance, for claims under the FET standard, not every violation of the latter will justify damages for loss of future profits - the State must have undertaken a specific commitment in this regard. ${ }^{251}$ An example of such commitment can be found in the recent renewable energy cases against Spain, which turn on a regulatory framework that guaranteed a certain above-market premium for investors, later overturned in response to the financial crisis. ${ }^{252}$

On this basis, let us consider how, under either of these approaches, current practice may be subject to critique. We will focus on two instances where the scope of application of the DCF method has been significantly expanded or reinforced. In both, this expansion has served to justify a claim to future profitability, in spite of the fact that the investor could not be said to have any legitimate expectation to it.

The first arises in cases where the investment is legally defined from the start as temporally limited, as established in the relevant contract, license or governmental authorisation. Where the State's breach brings that investment to an early end, tribunals have sometimes considered that damages should include, not only profits that the investor would have reaped during

249 See infra nn $260-61$ and corresponding text.

250 We join here several other authors who have argued for a breach-focused assessment of damages: Zachary Douglas, The International Law of Investment Claims (CUP 2009) 105; Desierto (n 5); Wolfgang Alschner, 'Aligning Loss and Liability - Towards an Integrated Assessment of Damages in Investment Arbitration' in Carpenter, Jansen and Pauwelyn (n 132) 283; Crespi Reghizzi (n 5); Ratner (n 5); Aisbett and Bonnitcha (n 24); Sergey Ripinsky, 'Damages Assessment in the Spanish Renewable Energy Arbitrations: First Awards and Alternative Compensation Approach Proposal' (2020) 2 TDM.

251 Zeno Crespi Reghizzi, 'Economic Crises and the Determination of Damages in Investment Disputes: Which Lesson from the Argentina Awards?' (2014) XXVIII Diritto del Commercio Internazionale 437, 458 (arguing that the concept of legitimate expectations as developed for violations of the FET standard should be extended to quantum).

252 See eg Eiserv Spain (n 45); Masdarv Spain (n 228); PV Investors v Spain (n 245). 
the initially established duration, but also those that would have been generated in the event of an agreed extension or renewal. To decide on this issue, the case law has sought to determine how probable it seems that an extension would have been granted (in a hypothetical but-for-the-breach scenario) and awarded damages for the loss of that opportunity if the probability was of some significance. Thus, the $C M E v C z e c h$ Republic tribunal presumed that the license in question would have been extended by the competent authorities, based on evidence that such extensions were 'renewed as a matter of ordinary administrative practice.'253 Conversely, the Burlington $v$ Ecuador tribunal refused any compensation for the loss of chance of an extension of the oil concession, noting that the claimant itself had been extremely pessimistic about this possibility and even valued it at zero. ${ }^{254}$ This is consistent with the overall trend to treat damages calculations as a purely factual assessment, since it reduces the question of whether the loss of the opportunity of a contract extension qualifies as compensable harm to a mere problem of the required standard of proof. 255

If, on the other hand, we accept that it is not enough to establish that an investor has an expectation of such an extension, and that it is moreover necessary that the expectation is a legitimate one, it becomes immediately clear that the usual approach is inappropriate. Rather than focusing on the sheer probability of an extension, tribunals ought to consider whether the investor had any entitlement to it. Such an entitlement could be found, as explained earlier, in the legal system of the host state or the contract itself whose extension is at stake - as in LETCO $v$ Liberia, where the Tribunal found that this possibility was included in the contract as an option of the investor and thus ought to be protected. ${ }^{256}$ Or it could be found in a representation of the State that is rendered enforceable by international investment protection standards - e.g. if the State has undertaken a commitment, of sufficient specificity to trigger the FET standard, to extend the contract or license beyond the initially agreed duration. On most occasions, however, the expectation of an extension lacks any legitimate basis and its loss should therefore not justify an additional claim for loss of future profits. This is so whenever the extension is dependent on a

\footnotetext{
253 CMEv Czech Rep (n 66) para 605.

254 Burlington $v$ Ecuador (n 154) para 282.

255 See also Gemplus, SA, SLP, SA, \& Gemplus Industrial SA de CV v United Mexican States, ICSID Case No ARB(AF)/o4/3, Award (16 June 2010) para 12-49 (rejecting compensation for the loss of a chance of an extension, as 'far too contingent, uncertain and unproven, lacking any sufficient factual basis').

256 Liberian Eastern Timber Corp v Government of the Rep of Liberia, ICSID Case No ARB/83/2, Award (31 March 1986).
} 
discretionary decision by the competent authorities, as is usually the case. The fact that discretion is involved does not simply mean that the future extension is uncertain or improbable (from a factual point of view), it also means that the beneficiary of the extension lacks any legitimate claim to it (from a legal point of view). The extension is, in other words, in the hands of the State, and to award damages for its loss would negate this. ${ }^{257}$

The second issue that we wish to focus on is the relevance of the DCF method in cases where that initial contract or license has not even been obtained yet. It arises in cases where the denial of the contract has been found to be in breach of the State's international obligations. Once again, the tendency in such cases is to approach this as a purely factual matter: the investor will be compensated if the probability of future profits is sufficiently established in a but-for hypothetical. The Lemire $v$ Ukraine arbitration is the best example of such an approach. In that case, the investor had been denied a series of radio frequencies in a number of tender processes, which the Tribunal found to be discriminatory and arbitrary and therefore in breach of the FET standard. Damages included lost profits, since the Tribunal concluded that, in a 'normal course of events', it is 'probable' that the investor would have succeeded in obtaining the desired radio licenses. ${ }^{258}$

The error is the same as before - by focusing exclusively on the probability of future profits, i.e. a purely factual question, the tribunal disregards the key question of whether the investor could be said to have had a legitimate claim to those future profits. In a case such as Lemire, the claim is extremely doubtful, since the State's breach consisted in wrongfully preventing the investor from participating in the public tender, rather than denying him any particular contract. To put it otherwise, FET had not been interpreted as granting in the circumstances a right to the radio licenses, but only to an administrative process free of discrimination and arbitrariness. ${ }^{259}$ The calculation of damages, however, does not reflect that this was the particular interest protected

257 When deciding, in spite of the discretionary nature of the decision to renew the contract or license, that the loss of that opportunity should be compensated, tribunals sometimes argue that the renewal would have been in the interest of the State (see eg TCC v Pakistan $(\mathrm{n} 7)$ para $\left.45^{2}\right)$. This quite transparently negates the discretionary nature of the decision, since the tribunal replaces the State in its appreciation of its best interest.

258 Joseph Charles Lemire v Ukraine, ICSID Case No ARB/o6/18, Award (28 March 2011) para 169 .

259 By contrast, tribunals have found in other cases that the investor is entitled under FET to the foregone contract (see Tethyan Copper Co Pty Ltd $v$ Islamic Rep of Pakistan, ICSID Case No ARB/12/1, Decision on Jurisdiction and Liability (10 November 2017); Bankswitch Ghana Ltd $v$ Republic of Ghana, UNCITRAL, Award (11 April 2014)). In such cases, it is not incoherent to award loss of profits. That said, it is extremely doubtful whether it ever 
under the investment treaty, since it focused instead on a purely economic assessment of the economic value of the lost opportunity. This decision is thus particularly illustrative of the disconnect that a purely 'factual' approach to damages creates between the breach and the remedy. It is also illustrative of how far arbitral practice may stray from that of other areas of the law. Indeed, rarely does a breach of a precontractual duty give rise in private law to a claim for the value of the contract that was not concluded (even if that conclusion would have otherwise seemed probable), ${ }^{260}$ and the same conclusion applies in administrative law to remedies for irregularities in tender processes (where recovery tends to be limited to incurred costs, as arbitrator Voss forcefully pointed out in his dissenting opinion). ${ }^{261}$

\subsection{Where Investors Have a Legitimate Expectation of Future Profits, to What Level of Future Profitability Are They Entitled?}

We have just seen how an investor's ability to obtain compensation/damages for the loss of future profits should depend on the existence of a legitimate expectation to the investment's profitability, as protected under the domestic law or through a specific commitment of the State that is rendered enforceable through investment treaty standards. If that legitimate expectation is established, the question that arises is how to determine the appropriate level of profits that the investor should be compensated for.

In general, the case law also approaches this issue as a purely factual determination. It will usually seek to establish what profitability seems most probable in the circumstances, with the help of financial experts. In the case of a DCF calculation, uncertainty will be factored in, either within the cash flows projections or through an appropriate discount rate. The problem is the same as the one we identified in the previous Section. By deferring entirely to economic considerations, tribunals have completely sidelined the key legal question of the extent to which the maintenance of projected income is a legally protected interest. In other words, rather than inquire what is the most probable future cash flow scenario, tribunals ought to ask what level of profits is the investor entitled to keep. The two need not coincide, as we will see below.

To determine whether the investor has a legitimate expectation of any particular level of profits, two scenarios ought to be distinguished. The first

makes sense to speak of a legitimate expectation to a particular contract or license, but that is another question that we cannot here address.

26o See eg Martijn W Hesselink and John Cartwright (eds), Precontractual Liability in European Private Law: The Common Core of European Private Law (CUP 2008).

261 Dissenting Opinion by Dr Jürgen Voss (11 March 2011) in Lemire v Ukriane (n 258) para $270 \mathrm{ff}$. 
is where a concrete level of profitability has been specifically promised. This may be through legislation, or the relevant contract, or via an undertaking that is found to bind the State under investment treaty protections (as various tribunals have concluded in the recent renewable energies cases against Spain). In such a case, there will be a strong presumption in favour of holding the State to the promised profitability, even if equitable considerations may justify some limitation - in particular, as mentioned earlier, the risk that the resulting award may cripple the State's finances, the history of the investor's conduct or the public policy rationale of the measure found to have been in violation of FET. ${ }^{262}$

The second scenario, the more frequent one, is where the investor has a legitimate expectation of future profits, but not of any particular level of profitability. How to determine then the appropriate extent of the investor's entitlement? The first thing to note here is the often forgotten truism that the level of profits of any particular business (and hence its economic value) is largely determined through law. ${ }^{263}$ The most obvious way that this is so is through tax law, inasmuch as the relevant State may decide to redistribute a greater or lesser part of the business' profits. But there are other ways: prices may be capped in the interest of consumers, new legislation may limit certain profit-generating activities if found to be environmentally harmful, etc. In all these instances, the business' market value is to a great degree decided on unilaterally by the State. ${ }^{264}$

What is more, in none of these instances will the exercise of the State's legitimate prerogatives usually offend investment treaty standards. Notably, other than in exceptional cases, investment tribunals will find that an increase in taxation complies with the State's obligations. ${ }^{265}$ Burlington $v$ Ecuador is particularly illustrative of the latitude given to the State in the exercise of its fiscal powers: the Tribunal concluded that a $99 \%$ tax on windfall profits was not expropriatory. ${ }^{266}$ Where the date of valuation is pushed forward to the date of the award, tribunals will also take into consideration any additional taxes legitimately adopted after the date of the breach, resulting in a reduction

262 See supra nn $234-35$ and corresponding text.

263 Robert L Hale, "The "Fair Value" Merry-Go-Round, 1898 to 1938: A Forty-Year Journey from Rates-Based-On-Value to Value-Based-On-Rates' (1938-1939) 33 Ill L Rev 517; Rasulov (n 232).

264 Girvan (n 26) 166-67.

265 Ali Lazem and Ilias Bantekas, 'The Treatment of Tax as Expropriation in International Investor-State Arbitration' (2015) 30 Arb Intl 1.

266 Burlington Resources, Inc v Rep of Ecuador, ICSID Case No ARB/o8/5, Decision on Liability (14 December 2012). 
of the final award. ${ }^{267}$ Similarly, to pick an example outside of taxation, it is doubtful how investment treaties could be interpreted to impede climate change-related legislation, involving for example restrictions on the extraction of fossil fuels that could leave many oil reserves as 'stranded assets', i.e. ones that have unexpectedly and suddenly lost most of their value and can no longer be profitably exploited. ${ }^{268}$

What this means is that, except where there are specific commitments by the State, the investor cannot be said to have a legitimate claim to the full stream of profits that at any particular time an investment is predicted to generate in the future. It may entertain a subjective expectation of reaping those profits, but not a legitimate one since their realisation is in the discretionary hands of the State. And yet this is precisely what current arbitral practice fails to recognise. Indeed, when confronted with the possibility of future regulatory interventions that may affect the investment's level of profitability, tribunals only consider it, if at all, as affecting the probability of those predicted profits actually materialising. In other words, they will either factor in an additional discount factor for 'regulatory risk', ${ }^{269}$ or more simply brush it aside as 'pure speculation.' ${ }^{270}$ By treating it as a mere risk, tribunals are effectively finding that the investor is entitled not only to future profits but also to maintaining current predictions of profits, even if subject to a discount factor. They are thus ignoring that the existence of legitimate of State prerogatives does not only affect the probability of that chance becoming true, but more fundamentally the legitimacy of the investor's claim to it. Indeed, how can it be said that the revenue of, say, a mining concession may be subject in the future to redistribution via increased taxation, and at the same time that the termination of that concession will entitle the investor to the entirety of current projections of profits? Similarly, does it not make a mockery of the principle of sovereignty over natural resources, to allow the State to retake control over the concession whilst simultaneously awarding the investor the full value of the mineral reserves? ${ }^{271}$

267 ConocoPhillips $v$ Venezuela $(\mathrm{n} 7)$ para $75^{1} \mathrm{ff}$.

268 Kyla Tienhaara, Lise Johnson and Michael Burger, 'Valuing Fossil Fuel Assets in an Era of Climate Disruption' (Investment Treaty News, 20 June 2020); Julia Dehm, 'Law and the "Value" of Future Expectations: Climate Change, Stranded Assets and Capitalist Dynamics' (VerfassungsBlog, 6 March 2020).

269 See eg $9 R E N$ Holding Sàrl v Kingdom of Spain, ICSID Case No ARB/15/15, Award (31 May 2019) para 412; SolEs Badajoz GmbH v Kingdom of Spain, ICSID Case No ARB $/ 15 / 38$, Award (31 July 2019) para 532.

270 ConocoPhillips $v$ Venezuela $(\mathrm{n} 7)$ para 722 (in relation to the risk of ulterior tax increases).

271 Edith Penrose, George Joffé and Paul Stevens, 'Nationalisation of a Foreign-Owned Property for a Public Purpose: An Economic Perspective on Appropriate Compensation' 
A similar conclusion can be reached via the doctrine of causation, as demonstrated recently by Sergey Ripinsky. ${ }^{272}$ As he explains, causation requires comparing the real-life situation produced by the breach with the hypothetical but-for scenario. In the latter, however, rather than assuming that the State would not have intervened at all, a tribunal should hypothesise that some intervention in the public interest would have happened, to the maximum extent allowed under international investment law. ${ }^{273}$ In doing so, the tribunal will proceed to a better balancing of the interests of investors with those of the respondent state (its population at large). ${ }^{274}$ This is not, however, how most of the tribunals calculated damages in those cases, imposing instead on the State (and its population) that it absorb the full costs of the economic crisis rather than have investors bear a proportionate share of them (despite the fact that this is something that the State can lawfully choose to do).

The realisation that profits largely depend on the applicable legal environment, and that determining that regulatory background forms part of the legitimate exercise of State prerogatives, means that tribunals cannot determine appropriate levels of future profits on any objective basis. The reconciliation of the legitimacy of those prerogatives with the legitimacy of the investor's claim to some measure of future profits, cannot be reduced to a factual operation - it involves necessarily some judgment about what is fair in the circumstances. Some form of equitable balancing of the various legitimate interests and prerogatives at stake is inevitable, which should lead tribunals to determine compensation for loss of profits based on a fair or reasonable rate of return. In other words, as argued already by Brownlie in his separate opinion in the $C M E$ case, investors cannot be said to be entitled to anything beyond a reasonable level of profits. ${ }^{275} \mathrm{By}$ limiting loss of profits according to a standard

(1992) 55 MLR 351, 361-62. A good example is Quiborax SA, Non Metallic Minerals SA and Allan Fosk Kaplún v Plurinational State of Bolivia, ICSID Case No ARB/o6/2, Award (16 September 2015), where Bolivia terminated several mining concessions that had been granted only two years earlier for an unlimited duration and subject to minimal taxation, leading the Tribunal to grant the investor compensation equal to the full value of the mineral reserves. Strikingly, the concessions had been acquired two years before termination for around USD 80o,ooo, but they were valued by the Tribunal, through the DCF method, at nearly USD 49 million.

272 Ripinsky (n 250). See also Thomas Wälde, 'Damages in Investment Arbitration: Are the Standards Different from Commercial Arbitration? The Need for Consistency' (2005) 6 JWIT 51.

273 Ripinsky (n 250) 14-19.

274 ibid 13.

275 Separate Opinion by Brownlie on the Issues at the Quantum Phase, CME v Czech Rep (n 66) (arguing for compensation on the basis of a reasonable rate of return given that 
of what is reasonable, tribunals will preserve the investor's right to profitability without thereby denying the legitimate ability of the State to intervene in the public interest.

Such an approach is similar to that found in public utility cases in the United States, ${ }^{276}$ which traditionally has also been justified as a necessary compromise given the entanglement of legitimate regulation with economic value. ${ }^{277}$ There is, moreover, nothing un-economic about such an approach, as economists who take seriously the inseparable connection between law and value have maintained. By analogy to the traditional concept of a 'normal return',278 which has a long history in economics, it has been argued that compensation for nationalisation should be limited by reference to the rate of return required for an enterprise to remain 'worthwhile to keep going'.279 The investor's 'economically legitimate expectations' should therefore be limited to that 'minimum necessary stream of profits.' ${ }^{280}$ Awarding compensation/damages on the basis of current projections of income, it is pointed out, is economically unsound since it allows investors to lay claim to abnormal gains (such as those derived from unjustified monopoly positions) and prevents any attempts by the State at correcting and redistributing those gains. ${ }^{281}$ It is interesting to note that this literature has tended to be completely ignored by scholarship on quantum, and, when it has not, it has been brushed aside as contrary to the principle of full compensation/reparation ${ }^{282}$ or because it 'allows the government to capture value at the direct expense of the investor'. ${ }^{283}$ Such critiques incorrectly assume a complete separation between law and value, as well as the objectivity of full compensation. They also of course ignore that such 'capture' by the State is for the most part legitimate under international investment law.

investment treaties seek to protect investment rather than property rights). See also Crespi Reghizzi ( $\left.\mathrm{n}_{5}\right) 62$.

276 Merrill (n 110) $124 \mathrm{ff}$.

277 Hale (n 263).

278 See Louis T Wells, 'Double Dipping in Arbitration Awards? An Economist Questions Damages Awarded to Karaha Bodas Company in Indonesia' (2003) 19 Arb Intl 471, 475; Stauffer (n 112).

279 Penrose, Joffé and Stevens (n 271) 365.

280 ibid.

281 See also George Joffé and others, 'Expropriation of Oil and Gas Investments: Historical, Legal and Economic Perspectives in a New Age of Resource Nationalism' (2009) 2 JWELB 3 .

282 Kantor (n 96).

283 Andrew B Derman and Andrew Melsheimer, 'A Commentary on "Expropriation of Oil and Gas Investments: Historical, Legal and Economic Perspectives in a New Age of Resource Nationalism"' (2009) 2 JWELB 163. 
The famous Aminoil award is a good illustration of what our suggested approach could look like in practice, in terms both of its justification and concrete operation. In relation to the termination of a long-term contract, the claimant argued that compensation for lost profits ought to be calculated on the basis of what the initial contract terms provided. The Tribunal did accept that the concession was income-generating and should be treated as such for the purposes of the calculation of compensation, i.e. that the investor did have a legitimate claim to future profits. It pointed out, however, that compensation should be calculated 'on a basis such as to warrant the upkeep of a flow of investment in the future'284 - in other words, the minimum level of profits necessary to make investment worthwhile. On this basis, it reasoned that there was no legitimate expectation to those initial terms remaining intact, given in particular the various changes and renegotiations that had already been implemented. Thus, the Tribunal concluded, the claimant was only entitled to a reasonable rate of return on its investment. Marboe describes this as a 'more flexible approach' to valuation, since it includes 'the possibility and legitimacy of alterations or adaptations of contractual provisions in long-term contracts. ${ }^{285}$ There is no reason, however, to limit such flexibility to long-term contracts, since alterations in the regulatory framework that affect the rate of return are equally legitimate. Beyond its conceptual merit, recent case law has also shown that this methodology is perfectly workable. In various episodes of the Spanish renewables saga, tribunals have found that the claimant's legitimate expectations of future profit were limited to a reasonable rate of return, ${ }^{286}$ as this was the rate that had been specifically guaranteed by Spain. ${ }^{287}$

284 Aminoil v Kuwait (n 81) para 147.

285 Marboe (n 3) para 5.124.

286 PV Investors $v$ Spain (n 245). See also Cavalum SGPS, SA v Kingdom of Spain, ICSID Case No ARB/15/34, Decision on Jurisdiction, Liability and Directions on Quantum (31 August 2020).

287 Thus, contrary to what we are here suggesting, the Tribunal did not adopt this measure of profitability in order to reach an appropriate balance between the different interests at stake, but on the basis of a specific State undertaking. Nevertheless, the case is illustrative of how tribunals should aim to connect the assessment of damages with an analysis of the investor's legitimate expectations (revealingly, the Tribunals in those awards explicitly fused the analysis of liability and quantum). 
In the debate around the legitimacy of ISDS, one of the most surprising arguments sometimes wielded by its advocates is the idea that the system cannot be said to be biased in favour of investors since they do not win in a majority of cases. $^{288}$ Surely the overall neutrality or balance of the system cannot depend on whether the numbers of wins and losses are symmetrical? Surely what matters is whether cases are adjudicated on the basis of appropriate principles, regardless of whether those principles translate into more or less victories for the investor or the State?

We hope to have shown that, when evaluating whether those principles are indeed appropriate, those that relate to quantum should be central to the enquiry. It is short-sighted to act as if all the ills of ISDS will be cured by focusing only on the traditional questions of the tribunal's jurisdiction or the scope of State behaviour that falls short of investor protection standards. The recent inclusion of damages in the reform agenda of the UNCITRAL Working Group III and in the modernisation of the ECT are encouraging signs - it shows that the general unease with which various mega-awards have been received is, at the very least, bringing attention to this issue. It is not, however, nearly enough.

First of all, if we are to take the calculation of compensation/damages truly seriously, it is indispensable that we realise it is not a merely technical operation, involving only fact-finding and inaccessible economic and financial expertise. It is precisely this misperception that has shielded these calculations from significant critical attention, and justified that we worry only about the consistency of awards, which seems to be the only real preoccupation. Quantifying damages is not a simple process of counting - it involves fundamental questions about what it is that must be counted.

Secondly, however, the misperception of quantum issues as only technical has not only had the effect of insulating it from critique. It also has justified that tribunals calculate compensation/damages in a certain way, leading to increasingly voluminous, sometimes colossal awards against the public purse. On the whole, we consider this evolution to be extremely questionable from a strictly legal perspective - not because of the numbers per se, but because of the principles that have been applied to reach them. It may well be the current arbitral consensus is now so entrenched that only treaty reform can realistically challenge it, in order to ensure, inter alia, that equitable considerations

288 Marboe (n 13) 3-4; Gloria M Álvarez and others, 'A Response to the Criticism Against ISDS by EFILA' (2017) 33 JIA 1, 4. 
are not excluded from the assessment of quantum, the relevance of FMV is limited to the specific circumstances that match that standard's underlying assumptions, and the loss of future profitability is compensable only where appropriate and in a reasonably limited way.

Nevertheless, it remains the case that the standard approach to the calculation of compensation/damages is premised on a series of myths and unjustifiable assumptions. Realising that this is so should already lead investment tribunals to thoroughly rethink these calculations as ultimately reflective of the legitimate expectations of investors, and hopefully consider new concrete ways - such as assessing compensation for loss of future profits based on a reasonable rate of return - through which they may truly bring justice to the assessment of quantum.

\section{Biographical Note}

Toni Marzal is Lecturer at the University Glasgow School of Law, where he is affiliated to the Glasgow Centre for International Law and Security as well as the Legal Theory research group.

\section{Acknowledgements}

I am grateful to Alexandre Belle for the research support, and to the friends and colleagues who commented on earlier versions of this work, including Anna Chadwick, James Devaney, Javier García Olmedo, Marco Goldoni, Cait Storr, Akbar Rasulov, Christian Tams and Pacôme Ziegler. Special thanks go also to Tatiana Alfonso Sierra for kindly inviting me to present at the ITAM, and Guillermo Estrada Adán at the IIJ-UNAM, and to the colleagues there who provided comments. 